
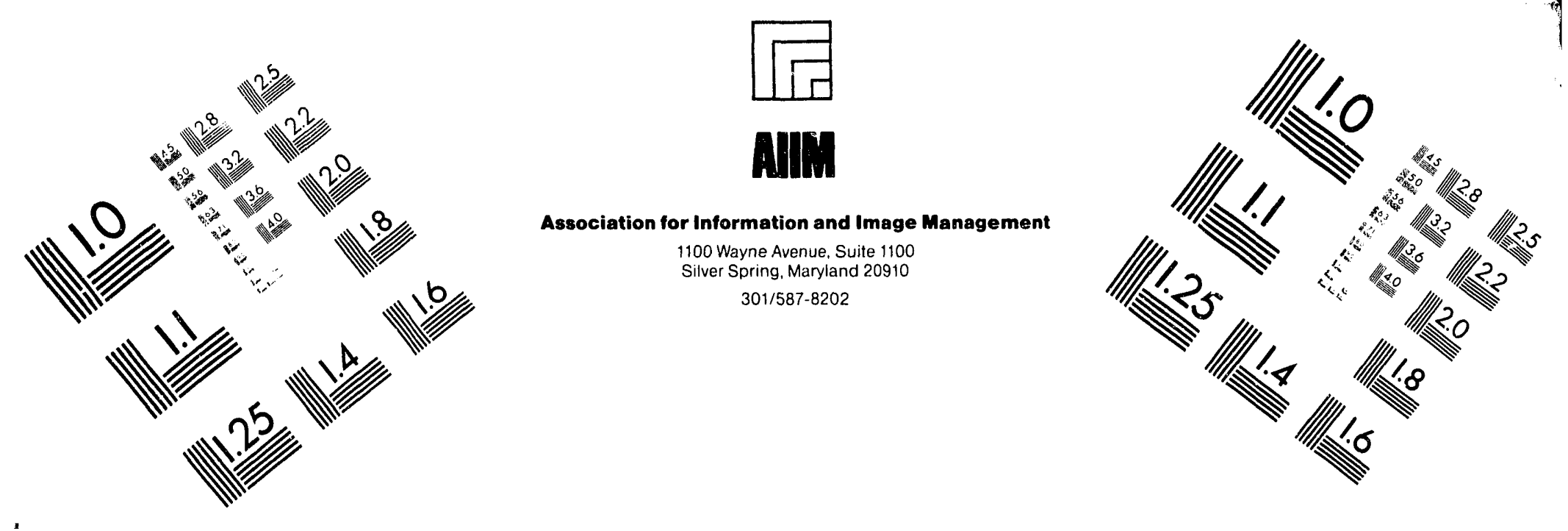

Centimeter

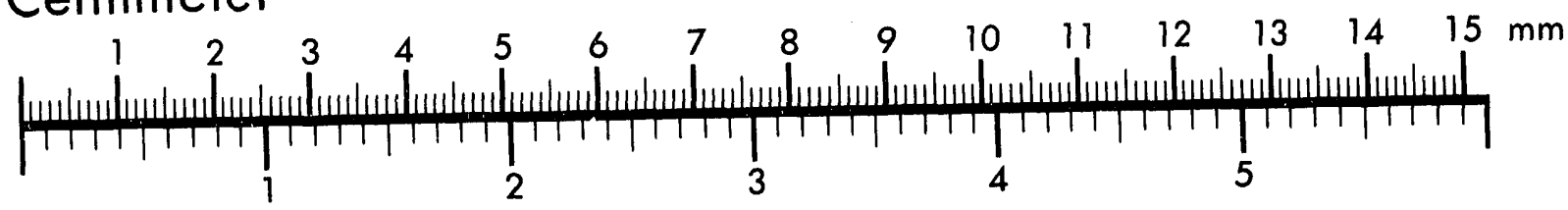
Inches
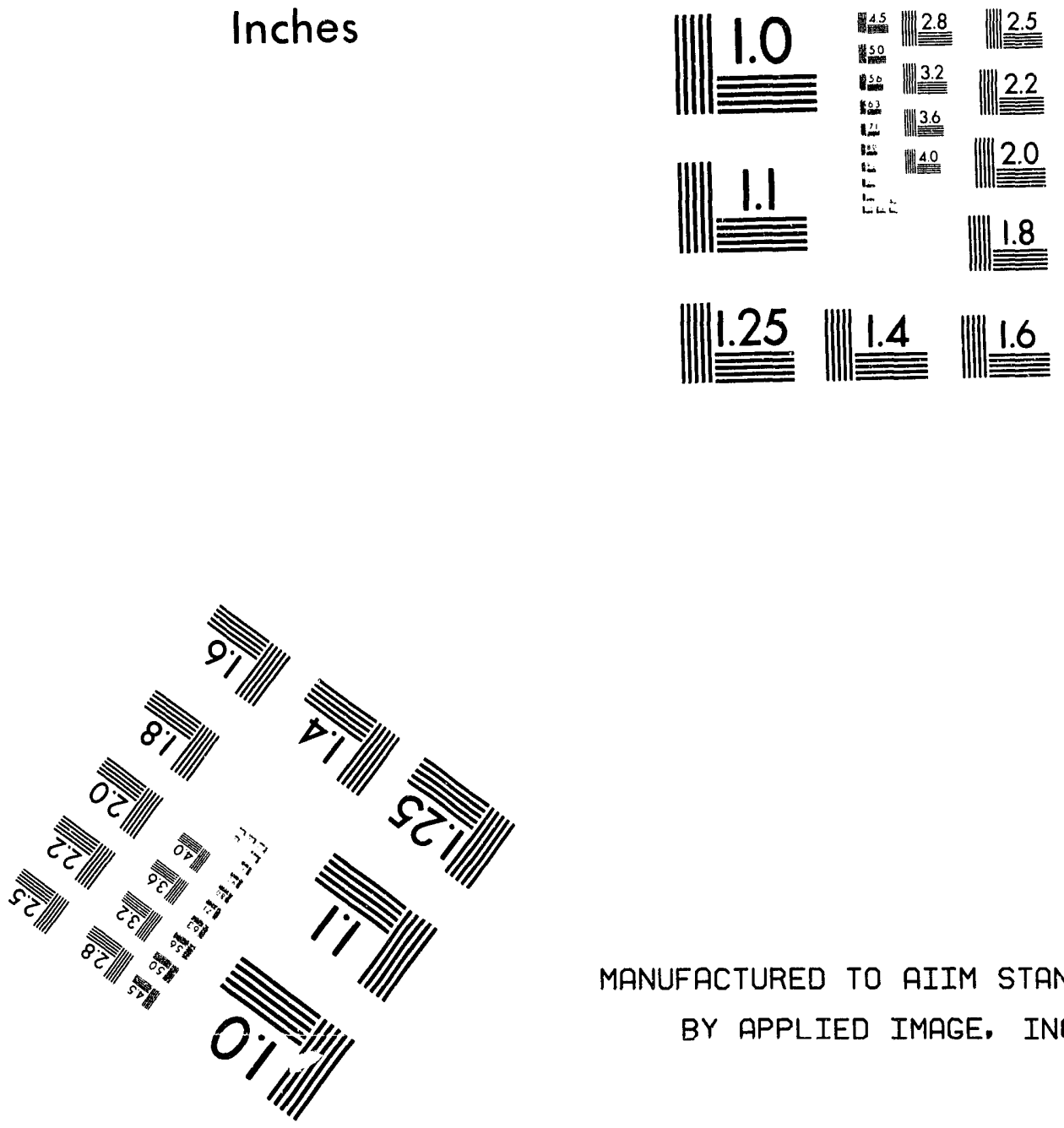

MANUFACTURED TO AIIM STANDARDS

BY APPLIED IMAGE. INC.

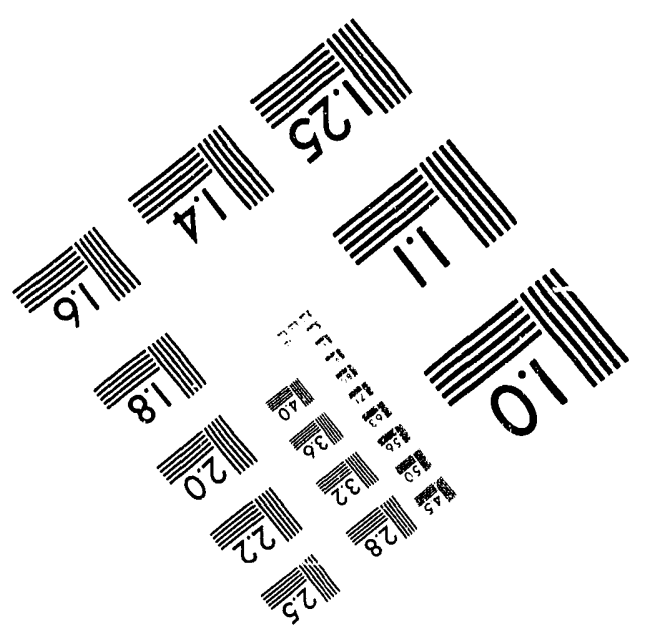



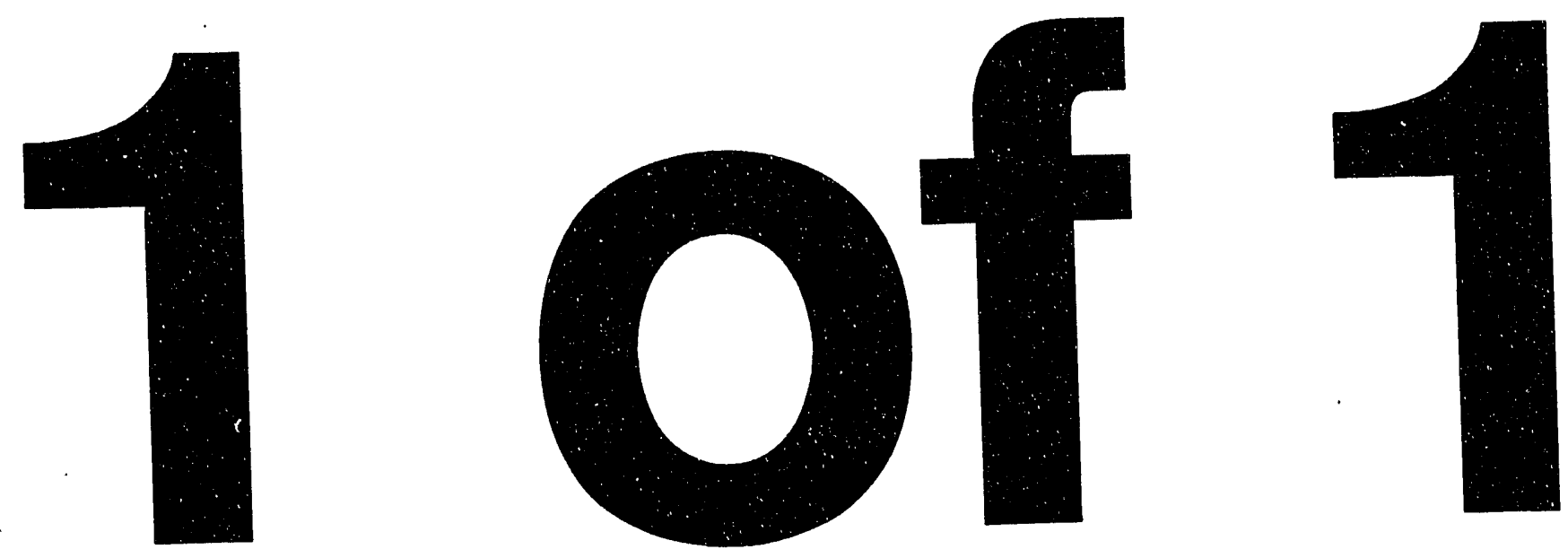
WHC-EP-0635

UC 600

\section{Assay Development Status Report for Total Cyanide}

B. C. Simpson

Westinghouse Hanford Company

T. E. Jones

K. H. Pool

Pacific Northwest Laboratory

Date Published

February 1993

Prepared for the U.S. Department of Energy Office of Environmental Restoration and Waste Management

\footnotetext{
(QP) Westinghouse

P.O. Box 1970

Hantord Company Richland, Washington 99352

Hanford Operations and Engineering Contractor for the

U.S. Department of Energy under Contract DE-AC06-87RL10930
}

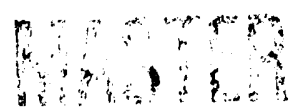

Approved for Public Release 


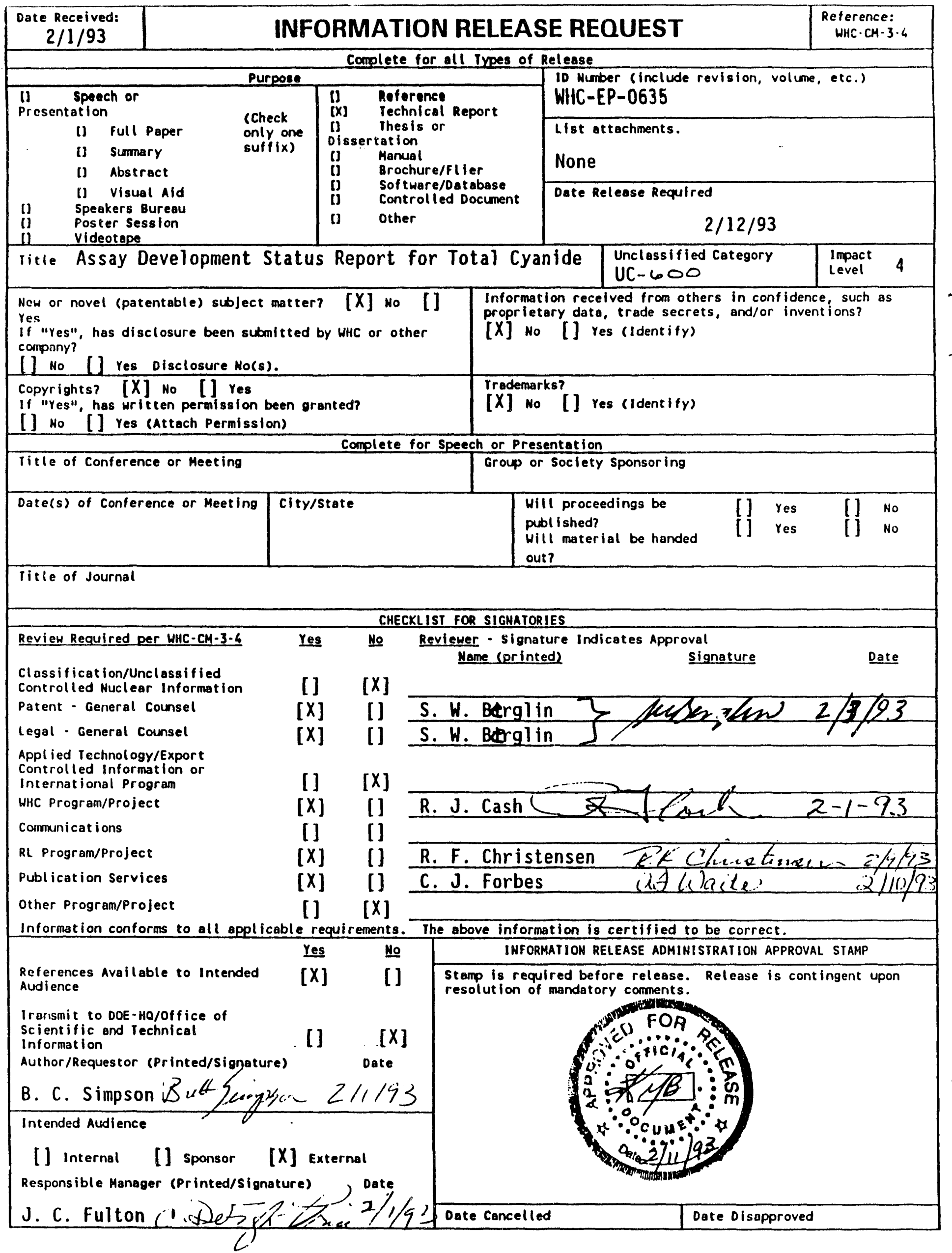


WHC-EP-0635

\section{CONTENTS}

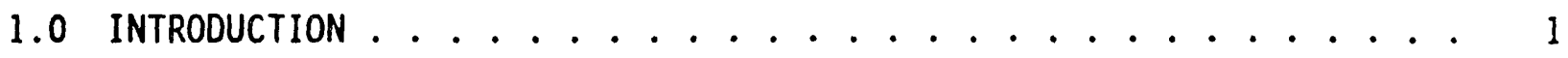

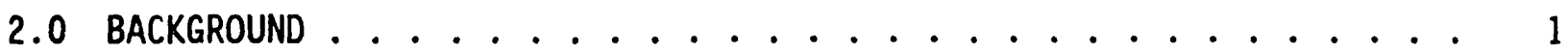

2.1 SUMMARY . . . . . . . . . . . . 1

2.2 UNREVIEWED SAFETY QUESTION DECLARATION $\ldots \ldots \ldots . . \ldots 1$

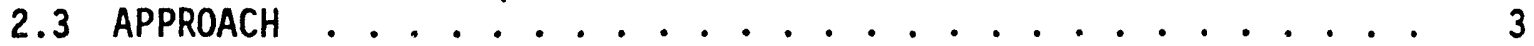

3.0 CURRENT ANALYTICAL TECHNIQUES .............. 5

3.1 ANALYTICAL FINDINGS--WESTINGHOUSE HANFORD COMPANY $\ldots \ldots \ldots$

3.1 .1 Beaker Test Report . . . . . . . . . . . . . . 5

3.1.2 Vendor Compound Analysis .............. 5

3.1.3 U-Plant Solids Characterization ........... 5

3.1.4 Miscellaneous sludge Analysis ........... 6

3.1.5 SY-101 Simulant Analysis ............. 6

3.2 ANALYTICAL FINDINGS--PACIFIC NORTHWEST LABORATORY . . . . . 6

3.3 INDIRECT MEASUREMENT . . . . . . . . . . . . . . 8

3.3.1 Differential Scanning Calorimetry and

Thermogravimetric Analyses ........... 9

4.0 CONTINUING EFFORTS . . . . . . . . . . . . . . . . 10

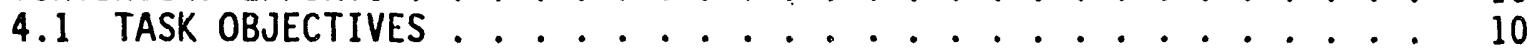

4.2 INSTRUMENTAL METHODS WITH SAMPLE PREPARATION SUBTASK $\ldots \ldots 10$

4.2.1 Dissolution Method Optimization ......... 10

4.2.2 Interferences with Solution Technique ....... 10

4.2.3 Interconversion of Cyanide Species .......... 10

4.2.4 Quantification of 'Cyanide Species ........... II

4.3 DIRECT METHODS SUBTASK . . . . . . . . . . . . . 11

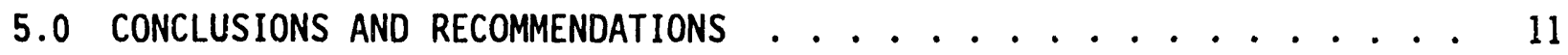

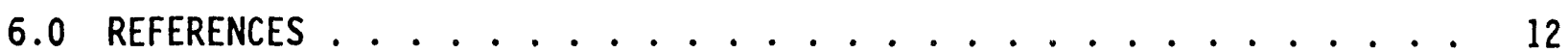

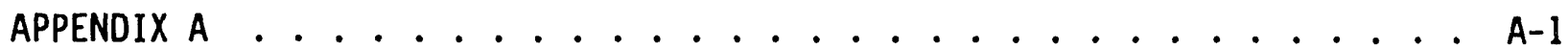

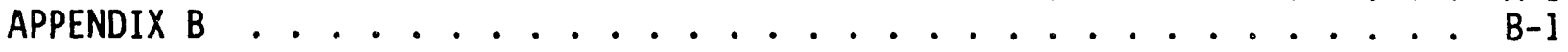


WHC-EP-0635

\section{LIST OF FIGURES}

1 Total CN Assay Range . . . . . . . . . . . . . . . . . 2

\section{LIST OF TABLES}

1 Known Ferrocyanide Materials Available for Testing . . . . . . . . 4

2 Total Cyanide Analysis Results for Core 34 Segment 2D Using

Proposed Method .. . . . . . . . . . . . . . . . 7

3 Total Cyanide Analysis Results for Knowns . . . . . . . . . . . 7

4 Total Cyanide Analysis Results for Core 34 Segment 2D

Samples Plus Spike..................... . 8

5 Total Carbon Analysis Results ................. . 8

6 Carbon Results at Total Organic Carbon Assay Conditions (700 ${ }^{\circ} \mathrm{C}$ furnace temperature) . . . . . . . . . . . . . 9

7 Carbon Results at Total Organic Carbon Assay Conditions (Hot Persulfate Method) ................... 9 
WHC-EP-0635

\section{ACRONYMS}

DSC

EDTA

EPA

FTIR

HOW-EIS

IC

PNL

SST

TGA

WHC differential scanning calorimetry ethylenediaminetetraacetic acid U.S. Environmental Protection Agency fourier transform infrared Hanford Defense Waste-Environmental Impact Statement ion chromatography

Pacific Northwest Laboratory single-shell tank

thermogravimetric analysis

Westinghouse Hanford Company 
WHC-EP-0635

This page intentionally left blank. 
WHC-EP-0635

\section{ASSAY DEVELOPMENT STATUS REPORT FOR TOTAL CYANIDE}

\subsection{INTRODUCTION}

A validated cyanide assay that is applicable to a variety of tank waste matrices is necessary to resolve certain waste tank safety issues and for purposes of overall waste characterization. The target for this effort is an assay with an applicable range of greater than $1,000 \mathrm{ppm}(0.10 \mathrm{wt} \%)$ total cyanide and a confidence level greater than $80 \%$. Figure 1 illustrates the operating regime of the proposed cyanide assay method.

The Assay Development Status Report for Total Cyanide will summarize the past experience with cyanide analyses on tank waste matrices and will rate the status of the analytical methods used to assay total cyanide ( $\mathrm{CN}^{-}$ion) in the tank waste matrices as acceptable or unacceptable. This paper will also briefly describe the current efforts for improving analytical resolution of the assays and the attempts at speciation.

\subsection{BACKGROUND}

\subsection{SUMMARY}

In the 1950 's, ${ }^{137} \mathrm{Cs}$ was scavenged during the reprocessing of single-shell tank (SST) waste by co-precipitating it along with sodium in nickel ferrocyanide sait, $\mathrm{Na}_{2-x} \mathrm{Cs} s_{x} \mathrm{NiFe}(\mathrm{CN})_{6}$. Heated ferrocyanide salts in combination with oxidizing agents, such as nitrate and nitrite, are known to be thermodynamically unstable, and their potential presence in the SST wastes has been identified as a safety issue. Preliminary identification of tanks of concern was made on the basis of $1,000 \mathrm{~g}$-moles of $\mathrm{Fe}(\mathrm{CN})_{6}^{-4}$ ion received, based on historical data (Postma 1992; Grigsby et al. 1992). Reliable total cyanide analysis data for SST materials are required to address the safety issue. However, it has not been possible to obtain reliable total cyanide analysis data for samples containing the nickel ferrocyanide materials using accepted, routine procedures because of the insolubility of the nickel ferrocyanide materials in acidic media. The situation was further exacerbated by the limited amount of ferrocyanide SST materials available and the need to have data on samples from small intervals along the length of the cores recovered from the waste tanks. A decision was made to delay total cyanide analyses of tank $\mathrm{C}-112$ core samples until a more reliable method could be developed.

\subsection{UNREVIEWED SAFETY QUESTION DECLARATION}

Efforts have been under way since the mid 1980's to evaluate the potential of a ferrocyanide explosion in Hanford Site SSTs (Burger and Scheele 1991; Burger 1984). In 1988, the Final Environmental Impact Statement 
Figure 1. Total CN Assay Range.

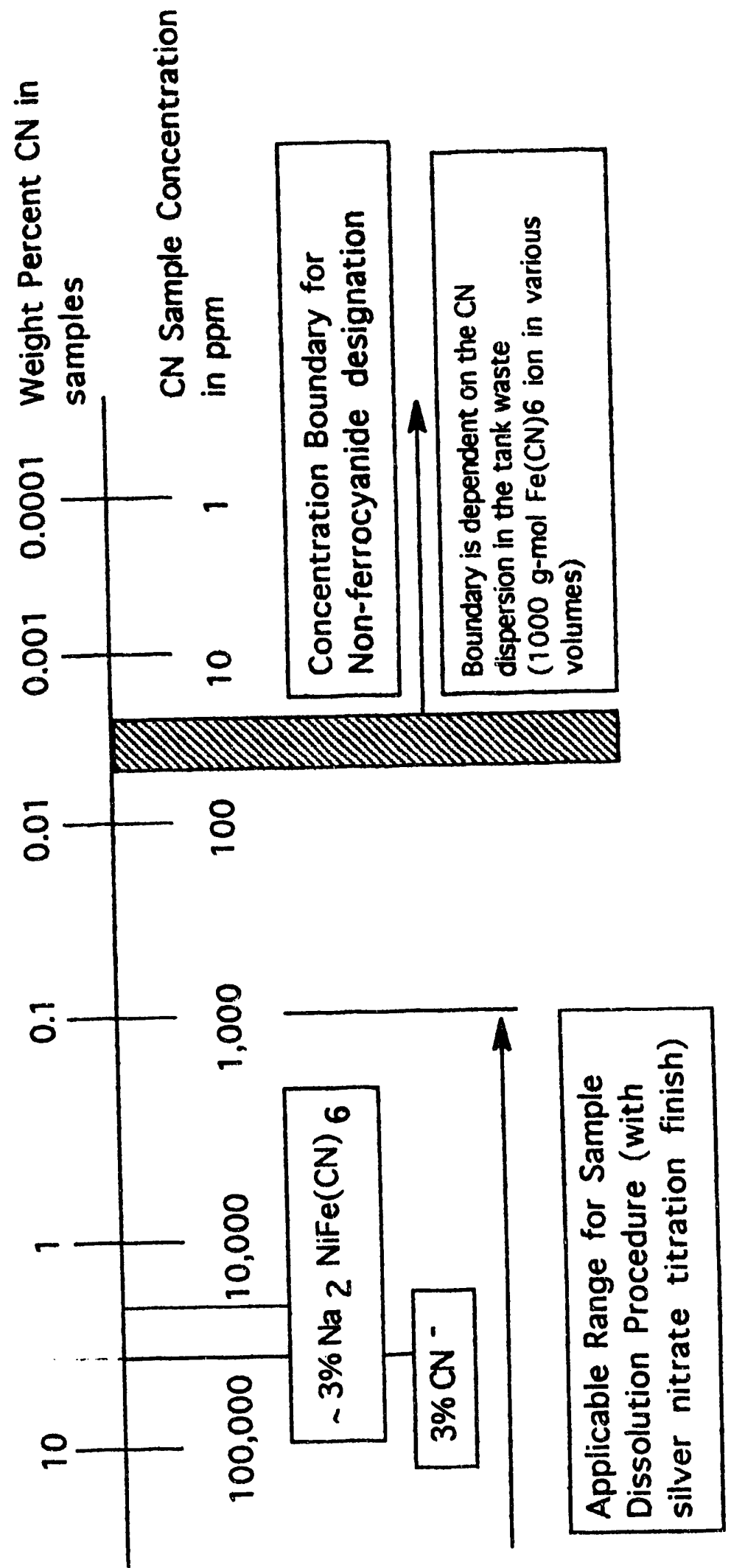


for the Disposal of Hanford Defense High Level, Transuranic, and Tank Wastes, hereinafter referred to as the final Hanford Defense Waste-Environmental Impact Statement (HDW-EIS) (DOE 1988) was issued. In the HDW-EIS it was projected that the bounding "worst-case" accident in a ferrocyanide tank would be an explosion resulting in a subsequent short-term radiation dose to the public of $200 \mathrm{mrem}$.

A recently completed General Accounting Office study (Peach 1990) postulates a greater "worst-case" accident with independently calculated doses one to two orders of magnitude greater than the HDW-EIS (DOE 1988). The potential for an exothermic reaction of this magnitude in the cesium-nickel ferrocyanide/sodium nitrate waste matrix is outside the bounds of the current safety analyses in those waste tanks suspected of containing 1,000 g-moles or more of ferrocyanide precipitates. A special Hanford Ferrocyanide Task Team was commissioned in September 1990 to address all issues involving the ferrocyanide tanks, including the consequences of a potential accident. On October 9, 1990, Secretary of Energy James D. Watkins announced that a supplemental environmental impact statement would be prepared that would contain an updated analysis of safety questions for the Hanford Site SSTS, including a hypothetical ferrocyanide explosion.

Using a computer model output (Jungfleisch 1984), process knowledge, and transfer records, 24 tanks were initially identified at the Hanford Site as containing 1,000 g-mol (465 lb) or more of ferrocyanide (as $\mathrm{Fe}(\mathrm{CN})_{6}^{-4}$ ion). Because the consequences of this safety condition were very much greater than those considered in the HDW-EIS (DOE 1988), the ferrocyanide issue was declared an unreviewed safety question in October 1990.

\subsection{APPROACH}

Scientists at Battelle-Pacific Northwest Laboratory (PNL) and Westinghouse Hanford Company (WHC) have been exploring various modifications and improvements to the U.S. Environmental Protection Agency (EPA)-accepted total cyanide analysis methods to make them more applicable to high-level radioactive samples. The present SW-846 (EPA 1984) method involves releasing the cyanide from the waste matrices as HCN by means of a reflux-distillation procedure. The cyanide is absorbed in a $\mathrm{NaOH}$ scrubber and the dissolved cyanide is determined colorimetrically. The following are three difficulties associated with this procedure.

- The EPA procedure calls for using nearly a liter of solution in the assay. When analyzing high-level waste materials, this generates a large amount of waste that must be disposed. Laboratory personnel have adapted the procedure to a microdistillation to reduce the amount of sample and solution necessary to perform the assay.

- There is the potential for a high bias interference from a combination of organics and high nitrate concentration in the sample matrices. The investigators are attempting to correct for this interference by controlling the $\mathrm{pH}$ in the distillation vessel. A pH level of about 4 in the distillation vessel greatly diminishes the co-distillation of potentially interfering species (e.g., $\mathrm{NO}_{\mathrm{x}}$ ). 
- The sample matrix itself is highly resistant to dissolution.

Thus, a number of new sample dissolution methods were tested on several ferrocyanide simulants. A sample dissolution method using an ethylenediamine/ ethylenediaminetetraacetic acid (EDTA) mixture was promising. A test plan was developed to evaluate the candidate methodology with excess sample material from SST C-112.

The primary approach used was to test the new dissolution methodology with reasonably well characterized ferrocyanide simulant materials, tank C-112 materials and C-112 materials spiked with the "known" ferrocyanide materials. The known ferrocyanide materials are listed in Table 1. A second approach was to analyze the same suite of samples with a furnace-type carbon analyzer. Results from previous tests have suggested that it might be possible to quantify selected groups of carbon compounds by operating the furnace at selected temperatures. Organic carbon can be converted to carbon dioxide at relatively low temperatures $\left(400-500^{\circ} \mathrm{C}\right)$, while ferrocyanide carbon would be converted to carbon dioxide at a higher temperature $\left(700^{\circ} \mathrm{C}\right)$. At very high temperatures $\left(1,000{ }^{\circ} \mathrm{C}\right)$, all carbon is expelled as carbon dioxide. However, in the presence of nitrates and nitrites, the synthetic ferrocyanide sludges have been observed to react at about $250^{\circ} \mathrm{C}$ (Fauske 1992). The exact temperature for each of these processes appears to be a function of the sample matrix. In spite of the uncertainties, it was felt that the carbon measurements would provide an estimate of the upper limit of the amount of carbon (and thus total cyanide) in the SST C-112 materials. The differential scanning calorimetry (DSC) measurements routinely made on SST core materials also provide an energy-based estimate of the upper concentration limit of ferrocyanide in the SST materials. In addition to the wet chemical assays; investigation of simulant materials and tank waste matrices using nondestructive technologies, such as fourier transform infrared (FTIR) and Raman spectroscopy, for characterization will continue.

Table 1. Known Ferrocyanide Materials Available for Testing.

\begin{tabular}{|l|c|c|c|}
\hline \multicolumn{1}{|c|}{ Material } & Name and Source & (\% Cyanide) & (\% Carbon) \\
\hline $\mathrm{Na}_{2} \mathrm{NiFe}(\mathrm{CN})_{6}$ & WhC-2 Unwashed & 27.7 & 12.8 \\
\hline $\mathrm{Na}_{2} \mathrm{NiFe}(\mathrm{CN})_{6}$ & $\begin{array}{c}\text { FeCN-36 } \\
\text { Tingey prep) }\end{array}$ & 34.5 & 15.9 \\
\hline $\mathrm{K}_{4} \mathrm{Fe}(\mathrm{CN})_{6} \cdot 3 \mathrm{H}_{2} \mathrm{O}$ & Vendor & 37.0 & 17.1 \\
\hline
\end{tabular}




\subsection{CURRENT ANALYTICAL TECHRIQUES}

\subsection{ANALYTICAL FINDINGS--WESTINGHOUSE HANFORD COMPANY}

The 222-S Laboratory has had experience with total cyanide measurements on five previous occasions. Assays were done on samples with no prior sample preparation, samples that had been prepared by dissolution, and sometimes both. A brief summary of the results from those tests follow.

\subsubsection{Beaker Test Report.}

Total $\mathrm{CN}^{-}$content was requested on synthetic nickel ferrocyanide sludges and supernates where the total potassium ferrocyanide additions were known in the Report of Beaker Tests of Ferrocyanide Scavenging Flow Sheets, WHC-SD-WM-TRP-071 Rev 0, (Bechtold 1991b). The CN performance was spotty, but reliable in cases where adequate amounts of $\mathrm{CN}^{-}$were available. There was some loss of recovery in the very richest mixtures. Tables 5-19 through 5-21 and A-27 through A-39 (excerpted from the report and included as Appendix $A$ in this report) present assay results and mass balance checks. Also, the exothermic response of the synthetic sludge samples increased with increased cyanide values (refer to Figure 6.4, also included in Appendix A).

Conclusion: The $\mathrm{CN}^{-}$assay method functioned for these samples and was appropriate for semiquantitative measures of cyanide content in ferrocyanide spiked sludges.

\subsubsection{Vendor Compound Analysis}

The "pure" vendor-prepared sodium nickel ferrocyanide (WHC-2) was analyzed after dissolution in the series of experiments reported in Analysis of Vendor Prepared Sodium Nickel Ferrocyanide, Internal Memo 28110-PCL91-086 (Bechtold 1991a). Results gave a molar ratio of $5.6 \mathrm{CN}^{-}: 1 \mathrm{Fe}: 1 \mathrm{Ni}$ and al so found $\mathrm{SO}_{4}^{-2}$ as a major impurity. Thermal gravimetric analys is of the material indicated approximately 5.4 waters of hydration. Total $\mathrm{CN}^{-}$assay results were in reasonable agreement with PNL's analys is (Total $\mathrm{CN}^{-}--W H C$ : 26.4 wt \%; PNL: 27.7 wt\%).

Conclusion: $\mathrm{CN}^{-}$assay method, with dissolution sample preparation step, is appropriate for use on these samples.

\subsubsection{U-Plant Solids Characterization}

U-Plant sludge simulant material was analyzed in Analysis of In-Plant Ferrocyanide Solids, Internal Memo 12110-PCL92-014 (Bechtold 1992). Total CN analyses were done as well as a limited physical and chemical characterization. There were several different sample preparation treatments performed on the specimens. Results of the composite sludge analysis had a 
molar ratio of $0.8 \mathrm{CN}^{-}: 1 \mathrm{Fe}: 0.1 \mathrm{Ni}$. Total cyanide is approximately 0.10 wt\%. The material was mostly water (61 wt\%, after centrifugation) and had a weak exothermic response when examined using DSC, consistent with the low cyanide content.

Conclusion: $\mathrm{CN}^{-}$assay method, with dissolution sample preparation step, is appropriate for use on these samples.

\subsubsection{Miscellaneous Sludge Analysis}

Miscellaneous $\mathrm{CN}^{-}$analyses were performed on dry tank sludges that had been stored in the laboratory for over 10 years. On examination, none of the samples had more than background values of $\mathrm{CN}^{-}$. Analyses were performed without sample preparation. Four spike recoveries were done on the samples; the lowest recovery was $94 \%$.

Conclusion: The $\mathrm{CN}^{-}$assay results suggest the method functioned without the sample preparation step for these samples. The sample matrices may have been more tractable to analysis than the ferrocyanide simulants.

\subsubsection{SY-101 Simulant Analysis}

Two blind standards made from synthetic glycolate-containing SY-101 slurry spiked with sodium sulfate and potassium ferrocyanide (not sodium nickel ferrocyanide) were made up and submitted for analysis. Total cyanide analysis was performed on the standards.

$1^{\text {st }} \mathrm{Bl}$ ind Standard Calculated $\mathrm{CN}^{-}: 45.1 \mathrm{ppm}$.

Found $\mathrm{CN}^{-}: 44.2 \mathrm{ppm}, 45.1 \mathrm{ppm}$.

$2^{\text {nd }} \mathrm{Bl}$ ind Standard Calculated $\mathrm{CN}^{-}: 72 \mathrm{ppm}$

Found $\mathrm{CN}^{-}: 57.8 \mathrm{ppm}, 58.1 \mathrm{ppm}$.

Conclusion: The $\mathrm{CN}^{-}$assay method somewhat functioned for these samples and was appropriate for semiquantitative measures of cyanide content in non-ferrocyanide sludges.

\subsection{ANALYTICAL FINDINGS--PACIFIC NORTHWEST LABORATORY}

PNL is under contract to WHC to develop an improved tota? cyanide assay that is appropriate for use on several different waste matrices. The method that has been developed requires sample dissolution in an EDTA/ethylenediamine preparation and uses a microdistillation separation with an argentometric titration. Scoping results from the initial trials can be found in Appendix A. Further results using the polished procedure are presented here. The assay is presently undergoing validation trials for approval. A brief description of the assay procedure and the validation test plan is attached as Appendix B.

Tctal cyanide in Core 34 segment 20 material was found to be 0.45 wt\% on a wet basis or $0.94 \mathrm{wt} \%$ for a dry sample. The reliability of the method can 
be inferred from an examination of the data on arialyses of the knowns (refer to Table 2). Analyses of the "knowns" gave about $70 \%$ to $90 \%$ recoveries and best results were obtained when the samples were dissolved prior to analysis (refer to Table 3). Spike recoveries for Core 34 material averaged about $85 \%$ (refer to Table 4). Therefore, the total cyanide measurement in the sample could be biased 15 to $20 \%$ low. An upper limit for total cyanide could be $\sim 0.6$ wt\% (wet) or 1.3 wt\% (dry).

Table 2. Total Cyanide Analysis Results for Core 34 Segment 20 Using Proposed Method.

\begin{tabular}{|l|c|c|}
\hline \multicolumn{1}{|c|}{ Sample/Standards } & No. of Assays & \% Cyanide \\
\hline Core 34 Segment 2D & 5 & $0.45 \pm 0.06$ \\
\hline Blank & 2 & $\sim 0.02^{*}$ \\
\hline $\begin{array}{l}\text { Core 34 Segment 2D } \\
\text { (w/0 pretreatment) }\end{array}$ & 1 & 0.18 \\
\hline
\end{tabular}

*-Blank value estimated based on $\sim 20 \mathrm{ug} \mathrm{CN}^{-}$found in blank and a hypothetical $0.1 \mathrm{~g}$ sample size.

Table 3. Total Cyanide Analysis Results for Knowns.

\begin{tabular}{|l|c|c|c|}
\hline \multicolumn{1}{|c|}{ Knowns } & \% $\mathrm{CN}^{-}$ & No. of Assays & \% Recovery as $\mathrm{CN}^{-}$ \\
\hline WHC-2 Unwashed & 27.7 & 2 & 95,89 \\
\hline FeCN-36 & 34.5 & 3 & 69,64, and $96^{* *}$ \\
\hline
\end{tabular}

*- - The $96 \%$ recovery was obtained when the FeCN-36 material was pre-dissolved prior to introduction of the sample into the distillation apparatus.

Aliquots of the Core 34 segment 20 sample were spiked with "known" ferrocyanide materials and total cyanide analyses were completed. The results are presented in Table 4. The purpose of this test was to assess any sample matrix effects on the analytical method. Two nickel ferrocyanide (WHC-2 Unwashed and $\mathrm{FeCN}-36$ ) and potassium ferrocyanide were used as spiking compounds. 
Table 4. Total Cyanide Analysis Results for Core 34 Segment 2D Samples Plus Spike.

\begin{tabular}{|l|c|c|}
\hline \multicolumn{1}{|c|}{ Sample + Spike } & No. of Assays & $\%$ Spike Recovery as CN \\
\hline $\begin{array}{l}\text { Core 34 Segment 2D } \\
+ \text { WHC-2 Unwashed }\end{array}$ & 3 & 86,88, and 88 \\
\hline $\begin{array}{l}\text { Core 34 seg. 2D } \\
+ \text { FeCN-36 }\end{array}$ & 3 & 83,86 , and $96^{* * *}$ \\
\hline $\begin{array}{l}\text { Core 34 seg. 2D } \\
+\mathrm{K}_{4} \mathrm{Fe}(\mathrm{CN})_{6}\end{array}$ & 1 & 85 \\
\hline
\end{tabular}

\subsection{INDIRECT MEASUREMENT}

Although the total cyanide values discussed above are internally consistent, there is the possibility that the analytical method could consistentiy fail to recover a significant fraction of cyanide in the sample. Two other analytical measurements provide additional insight into this question, total carbon analysis and DSC. Total carbon analysis would include carbon from all sources, even cyanide. The exothermic response from DSC can be used to infer total cyanide or ferrocyanide concentration. The higher the ferrocyanide content in the sample (Tables 5, 6, and 7), the greater the exothermic behavior during the DSC analysis.

Table 5. Total Carbon Analysis Results.

\begin{tabular}{|l|c|c|c|}
\hline \multicolumn{4}{|c|}{ Carbon Analyses by Furnace Technique (1,000 ${ }^{\circ} \mathrm{C}$ furnace temperature) } \\
\hline Sample & No. of Assays & Results (as \% carbon) & $\%$ Recovery \\
\hline Core 34 seg 2D & 3 & $1.12 \pm 0.16$ & -- \\
\hline $\mathrm{Na}_{4} \mathrm{Fe}(\mathrm{CN})_{6} \cdot 10 \mathrm{H}_{2} \mathrm{O}$ & 3 & $15.5 \pm 0.3$ & 104 \\
\hline $\mathrm{WHC}-2$ washed & 2 & 17.7 & 99 \\
\hline $\begin{array}{l}\text { Core } 34 \text { seg. } 20 \\
+\mathrm{Na}\end{array}$ & 1 & -- & $127^{*}$ \\
\hline $\begin{array}{l}\text { Core } 34 \text { seg } \\
+ \\
+\mathrm{WHC}-2 \text { Washed }\end{array}$ & 1 & -- & $99^{\star}$ \\
\hline
\end{tabular}

"--Percent Spike Recovery. 
Table 6. Carbon Results at Total Organic Carbon Assay Conditions ( $700{ }^{\circ} \mathrm{C}$ furnace temperature).

\begin{tabular}{|l|c|c|}
\hline \multicolumn{1}{|c|}{ Sample } & Results (in \% carbon) & \% Recovery \\
\hline $\begin{array}{l}\mathrm{Na}_{4} \mathrm{Fe}(\mathrm{CN})_{6} \cdot 1 \mathrm{H}_{2} \mathrm{O} \\
(\mathrm{Theoretical}=14.89)\end{array}$ & $13.3 \% \mathrm{C}$ and 12.5 & 89.3 and 84.0 \\
\hline $\begin{array}{l}\text { WHC-2 washed } \\
(\text { Theoretical }=17.9)\end{array}$ & $17.8 \% \mathrm{C}$ & 99.4 \\
\hline
\end{tabular}

Table 7. Carbon Results at Total Organic Carbon Assay Conditions (Hot Persulfate Method').

\begin{tabular}{|l|c|c|}
\hline \multicolumn{1}{|c|}{ Sample } & Results (in \% carbon) & \% Recovery \\
\hline $\begin{array}{l}\mathrm{Na}_{4} \mathrm{Fe}(\mathrm{CN})_{6} \cdot 1 \mathrm{H}_{2} \mathrm{O} \\
\text { theoretical }\end{array}$ & 1.0 to $1.9 \%$ & 6.7 to $12.1 \%$ of theoretical \\
\hline WHC-2 washed & 10.0 to $10.5 \%$ & 57 to $59 \%$ of theoretical \\
\hline
\end{tabular}

${ }^{1}$ The hot persulfate method dissolves a sample in a sulfuric acid solution $\left(90^{\circ} \mathrm{C}+\right.$ ) to liberate inorganic carbon (carbonate). $\mathrm{K}_{2} \mathrm{~S}_{2} \mathrm{O}_{8}$ is then added and organic carbon is converted to $\mathrm{CO}_{2}$, which is measured by conductivity. The poor performance of the hot persulfate method suggests incomplete solubilization of the sample.

The total carbon value of $1.12 \%$ in the Core 34 sample would include all forms of carbon that were present in the sample such as carbonate, bicarbonate, organics such as normal paraffin hydrocarbon, as well as cyanide. If all of the carbon found was present as cyanide, then the upper limit for total cyanide would be $\sim 2.5 \%$ (dry). Because the total cyanide value range (0.94-1.3\%) is less than the value for total carbon, if reported as total cyanide $(\sim 2.5 \%)$, the results from these assays are relatively consistent.

\subsubsection{Differential Scanning Calorimetry and Thermogravimetric Analyses}

DSC and thermogravimetric analyses (TGA) were performed as part of physical characterization of the In-Farm simulants and the C-112 core samples. DSC provides thermal decomposition temperatures, heats of reactions, and reaction temperatures, while TGA provides mass changes as a function of temperature. These measurements can be used to estimate concentrations of reactive components in a sample. Previous studies of sodium and cesium nickel ferrocyanides have shown that an exotherm is expected in the region of 300 to $425{ }^{\circ} \mathrm{C}$, which corresponds to the decomposition of ferrocyanide. Such exotherms were observed in the DSC analysis of the C-112 sample with an enthalpies ranging from -3 to $-38 \mathrm{cal} / \mathrm{g}$ dry sample. The upper limit for 
total cyanide in this sample, based on the highest enthalpy value, would be estimated to be 2 wt\% cyanide (dry). Thus, DSC results are consistent with the total cyanide value reported above.

\subsection{CONTINUING EFFORTS}

\subsection{TASK OBJECTIVES}

One of the goals of the Ferrocyanide Safety Program is to establish qualified analytical procedures for the quantitative measurement of cyanide species within ferrocyanide tank waste through the use of simulated ferrocyanide flowsheet waste. Based on experience gained in this task, a recommended technical procedure has been drafted. This procedure presumably will be used by the laboratory personnel at the 325 Laboratory for the analysis of ferrocyanide tank core samples, with eventual technology transfer to the 222-S Laboratory.

\subsection{INSTRUMENTAL METHODS WITH SAAPLE PREPARATION SUBTASK}

The goal of this subtask is to establish methods for the detection and speciation of cyanide species in prepared ferrocyanide tank waste simulants by instrumental methods. Instrumental methods analyses for ferrocyanides include using FTIR and ion chromatography (IC) techniques on solutions prepared from dissolved ferrocyanide flowsheet materials. This procedure presumably will be developed and then used by the operators of the "hot" FTIR and IC equipment to be deployed in the 325 Building.

\subsubsection{Dissolution Method Optimization}

Dissolution techniques will be optimized using existing simulated waste materials. Using the EDTA/ethylenediamine dissolution method developed in fiscal year 1992 as a starting point, optimum solvent solute ratios, temperature, complexants, etc., will be explored. Simulants to be used include U-Plant, In-Farm 1, In-Farm 2, J. M. Tingey prepared $\mathrm{Na}_{2} \mathrm{NiFe}(\mathrm{CN})_{6}$, vendor-prepared $\mathrm{Na}_{2} \mathrm{NiFe}(\mathrm{CN})_{6}$, and $\mathrm{Cs}_{2} \mathrm{NiFe}(\mathrm{CN})_{6}$.

\subsubsection{Interferences with Solution Technique}

IC and solution infrared techniques will be studied to determine the extent that species such as $\mathrm{NO}_{3}^{-}, \mathrm{NO}_{2}^{-}, \mathrm{CrO}_{4}^{-2}, \mathrm{BiPO}_{4}, \mathrm{OH}^{-}$, etc. may interfere with the detection or quantitation of cyanide species of interest.

\subsubsection{Interconversion of Cyanide Species}

The interconversion of oxidation states of $\mathrm{Fe}^{+2}$ and $\mathrm{Fe}^{+3}$ in the ferro- and ferricyanide complexes can be influenced by many factors relating to the redox properties of the matrix. These factors include the concentration and nature 
of reducing species in solution (e.g., organics or oxidizing species such as oxy-anions $\left[\mathrm{NO}_{2}^{-}, \mathrm{NO}_{3}^{-}, \mathrm{CrO}_{4}^{-2}\right.$, etc.]) and the presence of complexing ligand (e.g., EDTA, nitrilotriacetic acid [NTA], oxalate, chloride, etc. The influence of typical redox active factors on the stability of $\mathrm{Fe}(\mathrm{CN})_{6}^{-4}$, $\mathrm{Fe}(\mathrm{CN})_{6}^{-3}$, and $\mathrm{CN}^{-}$will be assessed. These effects will be determined by using blanks and spikes during the dissolution of cyanide species in simulated wastes.

\subsubsection{Quantification of Cyanide Species}

Portions of the available simulants (In-Farm 1, In-Farm 2, and U-P1ant 2) and surplus core sample material (if available) will be repeatedly analyzed using Quality Control protocols that include duplicates, spikes (ferrocyanide, ferricyanide, and cyanide), and blanks. The data so obtained will be used to generate sufficient statistical information to verify analytical method efficacy with respect to reproducibility (precision), accuracy (spike recovery and bias), and preliminary control charts for the method.

\subsection{DIRECT METHODS SUBTASK}

Development of methods for "real-time" determination of cyanide species is needed. At present, there are no methods avaiiable for in situ or in-hot cell use for the characterization of cyanide species contained in ferrocyanide tank waste. The goal of this subtask is to establish methods for the detection and speciation of cyanide species in ferrocyanide tank wastes by direct methods. Direct methods include FTIR and Raman techniques on solid samples with little or no preparation. This task will focus on the chemistry side of the problem to identify the proper conditions for these methods to provide defensible analytical results.

Infrared and Raman techniques will be studied to determine the extent that species (e.g., $\mathrm{NaNO}_{3}, \mathrm{NaNO}_{2}, \mathrm{Na}_{2} \mathrm{CrO}_{4}, \mathrm{BiPO}_{4}, \mathrm{NaOH}$, etc.) may interfere with the detection or quantitation of cyanide species of interest. The solids will be selected based on their probability for interfering with the analyses and for their relative abundance in actual tank waste.

\subsection{CONCLUSIONS AND RECOMMENDATIONS}

Nickel and ferrocyanide compounds were added to certain process streams during the reprocessing of materials that had been stored in SSTs at the Hanford Site. These compounds were added to the process to separate ${ }^{137} \mathrm{Cs}$ as the insoluble sodiun cesium nickel ferrocyanide salt. Insoluble nickel ferrocyanide salts have proven to be intractable to the application of "EPA-accepted" total cyanide analysis procedures. Poor analytical recoveries were observed because of the difficulty of re-solubilizing the ferrocyanide salts. A new sample dissolution methodology has been developed which routinely provides a recovery of approximately $90 \%$ for total cyanide for a number of nickel ferrocyanide materials. 
Total cyanide analytical results using the new methodology with SST C-112 core materials are consistent with upper limits of total cyanide estimated from independent calorimetry and total carbon measurements. All available data suggest the ethylenediamine/EDTA dissolution methodology provides a reasonable approach for semi-quantitative analysis of total cyanide. It appears likely that recoveries could be improved and could approach quantitative recovery by refining the in-cell dissolution steps. Based on these results it is recommended that analyses of the complete suite of samples from tank $\mathrm{C}-112$ be completed under the direct guidance of $\mathrm{Dr}$. Karl H. Pool using the new methodology. Further investigation of direct: sample analysis using spectroscopic methods will also be pursued.

\subsection{R'́LFERENCES}

Burger, L. L., 1984, Complexant Stability Investigation, Task 1, Forrocyanide Solids, PNL-5441, Pacific Northwest Laboratories, Richland, Washington.

Burger, L. L., and R. D. Scheele, 1991, The Reactivity of $\mathrm{Cs}_{2} \mathrm{NiFe}(\mathrm{CN})_{6}$ Towards Nitrate and Nitrite Salts, PNL-7550, Pacific Northwest taboratory, Richland, Washington.

Bechtold, D. B., 1991a, Analysis of Vendor Prepared Sodium Nickel Ferrocyanide, Internal Memo 28110-PCL91-086, Westinghouse Hanford Company, Richland, Washington.

Bechtold, D. B., 1991b, Report of Beaker Tests of Ferrocyanide Scavenging Flowsheets, WHC-SD-WM-TRP-071 Rev. 0, Westinghouse Hanford Company, Richland, Washington.

Bechtold, D. B., 1992, Analysis of In-Plant Ferrocyanide Solids, Internal Memo 12110-PCL92-014, Westinghouse Hanford Company, Richland, Washington.

DOE, 1988, "Record of Decision for the Final Environmental Impact Statement for the Disposal of Hanford High-Level Transuranic Waste,"

53 Federal Register 12449, U.S. Department of Energy, Washington, D.C.

EPA, 1984, Test Methods for Evaluating Solid Waste, Second Edition, Revised, SW-846, U.S. Environmental Protection Agency, Washington, D.C.

Fauske, H. K., 1932, Adiabatic Calorimetry and Reaction Propagation Rate Tests with Synthetic Ferrocyanide Materials Including U Plant-1, U Plant-2, In-Farm-1, In-Farm-2 and Vendor-Procured Sodium Nickel Ferrocyanide, WHC-SD-WM-RPT-054, Rev. 0, Westinghouse Hanford Company.

Grigsby, J. M., D. B. Bechtold, G. L. Borsheim, M. D. Crippen, D. R. Dickinson, G. L. Fox, D. W. Jeppson, M. Kummerer, J. D. McLaren, J. D. McCormack, A. Padilla, B. C. Simpson, D. D. Stepnewski, 1992, Ferrocyanide Waste Tank Hazard Assessment--Interim Report, WHC-SD-WM-RPT-032 Rev. 1, Westinghouse Hanford Company, Richland, Washington. 
Jungfleisch, F. M., 1984, TRAC: A Preliminary Estimation of the Waste Inventories in Hanford Tanks Through 1980, SD-WM-TI-057, Rockwell Hanford Operations, Richland, Washington.

Peach, J. D., 1990, Consequences of Explosion of Hanford's Single-Shell Tanks Are Understated, (Letter B-241479 to C. M. Synar, Chairman of Environment, Energy, and Natural Resources Subcommittee, Committee on Government Operations, House of Representatives), GAO/RCED-91-34, Genera1 Accounting Office, Washington, D.C.

Postma, A. K., H. Babad, and R. J. Cash, J. L. Deichman, 1992, Current Understanding of the Safety of Storing High-Level Waste Containing Ferrocyanide at the Hanford Site, WHC-EP-0531, Westinghouse Hanford Company, Richland, Washington. 
WHC-EP-0635

This page intentionally left blank. 
WHC-EP-0635

APPENDIX A

A-1 
WHC-EP-0635

This page intentionally left blank. 
Table 5-19. Summary Composition of In-Farm Supernate

\begin{tabular}{|c|c|c|c|c|c|}
\hline Analyte & $\begin{array}{c}\text { Value } \mathrm{mg} / \mathrm{L} \\
\text { or other }\end{array}$ & Weight $\times$ & Mole/Gram & Mole Ratio & $\begin{array}{c}\text { Charge } \\
\text { Equiv./ } \\
\text { Gram }\end{array}$ \\
\hline $\mathrm{Fe}$ & $1.71 \mathrm{e}+1$ & $1.26 \mathrm{e}-2$ & $2.26 \mathrm{e}-7$ & 1. & $4.52 \mathrm{e}-7$ \\
\hline $\mathrm{K}$ & $8.04 \mathrm{e}+2$ & $5.91 \mathrm{e}-2$ & $1.51 \mathrm{e}-5$ & $6.70 \mathrm{e}+1$ & $1.51 \mathrm{e}-5$ \\
\hline $\mathrm{Na}$ & $1.69 \mathrm{e}+5$ & $1.24 \mathrm{e}+1$ & $5.41 \mathrm{e}-3$ & $2.39 \mathrm{e}+4$ & $5.41 \mathrm{e}-3$ \\
\hline $\mathrm{Ni}$ & 2.24 & $1.65 \mathrm{e}-4$ & $2.81 \mathrm{e}-8$ & $1.24 \mathrm{e}-1$ & $5.62 \mathrm{e}-8$ \\
\hline $\mathrm{CN}^{-}$ & $4.32 \mathrm{e}+1$ & $3.18 \mathrm{e}-3$ & $1.22 \mathrm{e}-6$ & 5.41 & $-1.22 \mathrm{e}-6$ \\
\hline $\mathrm{Cl}^{-}$ & $1.26 \mathrm{e}+3$ & $9.26 \mathrm{e}-2$ & $2.61 \mathrm{e}-5$ & $1.16 \mathrm{e}+2$ & $-2.61 \mathrm{e}-5$ \\
\hline $\mathrm{NO}_{3}^{-}$ & $3.93 \mathrm{e}+5$ & $2.89 \mathrm{e}+1$ & $4.66 \mathrm{e}-3$ & $2.06 \mathrm{e}+4$ & $-4.66 \mathrm{e}-3$ \\
\hline $\mathrm{PO}^{3-}$ & $2.20 \mathrm{e}+4$ & 1.62 & $1.71 \mathrm{e}-4$ & $7.56 \mathrm{e}+2$ & $-5.12 \mathrm{e}-4$ \\
\hline $\mathrm{SO}_{2}^{2-}$ & $3.50 \mathrm{e}+4$ & 2.58 & $2.68 \mathrm{e}-4$ & $1.19 \mathrm{e}+3$ & $-5.37 \mathrm{e}-4$ \\
\hline $\mathrm{H}_{2} \mathrm{O}^{-}$ & $55.53 \%$ & $5.55 \mathrm{e}+1$ & & & \\
\hline $\mathrm{SpG}^{2}$ & 1.36 & & & & \\
\hline $\mathrm{PH}$ & 9.44 & & & & \\
\hline mass balance $\%$ & 101.16 & minus:plus charge ratio & 1.06 \\
\hline
\end{tabular}

\begin{tabular}{|c|c|c|c|c|c|}
\hline Analyte & $\begin{array}{l}\text { Value } \mathrm{mg} / \mathrm{g} \\
\text { or other }\end{array}$ & Weight $\%$ & Mole/Gram & $\begin{array}{l}\text { Mole } \\
\text { Ratio }\end{array}$ & $\begin{array}{l}\text { Charge } \\
\text { Equiv./ } \\
\text { Gram }\end{array}$ \\
\hline $\mathrm{Fe}$ & 5.99 & $5.99 e-1$ & $1.07 e-4$ & 1. & $2.15 e-4$ \\
\hline K & -- & - & - & -- & - \\
\hline $\mathrm{Na}$ & $1.26 e+2$ & $1.26 \mathrm{e}+1$ & $5.49 \mathrm{e}-3$ & $5.11 \mathrm{e}+1$ & $5.49 e-3$ \\
\hline $\mathrm{Ni}$ & 5.53 & $5.53 e-1$ & $9.43 e-5$ & $8.81 \mathrm{e}-1$ & $1.89 e-4$ \\
\hline $\mathrm{CN}^{-}$ & $1.36 \mathrm{e}+1$ & 1.36 & $5.22 e-4$ & 4.86 & $-5.22 e-4$ \\
\hline $\mathrm{Cl}^{\circ}$ & 2.98 & $2.98 \mathrm{e}-1$ & $8.41 \mathrm{e}-5$ & $7.86 e-1$ & $-8.41 e-5$ \\
\hline $\mathrm{NO}_{3}^{-}$ & $2.71 e+2$ & $2.71 e+1$ & $4.38 \mathrm{e}-3$ & $4.08 e+1$ & $-4.38 e-3$ \\
\hline $\mathrm{PO}_{6}^{3-}$ & $1.88 \mathrm{e}+1$ & 1.88 & $1.98 e-4$ & 1.84 & $-5.93 e-4$ \\
\hline $\mathrm{SO}_{4}^{2-}$ & $2.44 e+1$ & 2.44 & $2.53 e-4$ & 2.36 & $-5.07 e-4$ \\
\hline $\mathrm{XH}_{2} \mathrm{O}$ & $53.65 \%$ & $5.3 \% \mathrm{e}+1$ & & & \\
\hline \multicolumn{2}{|c|}{ mass balance $x$} & 101.53 & \multicolumn{2}{|c|}{ minus:plus charge ratio } & 1.03 \\
\hline
\end{tabular}


Table 5-21. Summary Composition of In-Farm Compacted Sludge

\begin{tabular}{|c|c|c|c|c|c|}
\hline Analyte & $\begin{array}{l}\text { Value } \mathrm{mg} / \mathrm{g} \\
\text { or other }\end{array}$ & Weight $x$ & Mole/Gram & $\begin{array}{l}\text { Mole } \\
\text { Rat to }\end{array}$ & $\begin{array}{l}\text { Charge } \\
\text { Equiv.l } \\
\text { Gram }\end{array}$ \\
\hline $\mathrm{Fe}$ & $3.00 e+1$ & 3.00 & $5.37 e-4$ & 1. & $1.07 e-5$ \\
\hline$K$ & 1.28 & $1.28 \mathrm{e}-1$ & $3.29 e-5$ & $6.13 e-2$ & $3.29 e-5$ \\
\hline $\mathrm{Na}$ & $1.19 \mathrm{e}+2$ & $1.19 e+1$ & $5.16 e-3$ & 9.59 & $5.16 e-3$ \\
\hline Ni & $3.11 \mathrm{e}+1$ & 3.11 & $5.29 e-4$ & $9.85 e-1$ & $1.06 \mathrm{e}-3$ \\
\hline $\mathrm{CN}^{-}$ & $7.98 e+1$ & 7.98 & $3.07 e-3$ & 5.71 & $-3.07 e-3$ \\
\hline $\mathrm{Cl}^{\circ}$ & 4.65 & $4.65 e-1$ & $1.31 \mathrm{e}-4$ & $2.44 e-1$ & $-1.31 e-4$ \\
\hline $\mathrm{NO}_{3}^{-}$ & $2.40 e+2$ & $2.40 \mathrm{e}+1$ & $3.87 e-3$ & 7.19 & $-3.87 e-3$ \\
\hline $\mathrm{PO}_{4}^{3-}$ & $1.84 e+1$ & 1.84 & $1.94 e-4$ & $3.61 e-1$ & $-5.81 \mathrm{e}-4$ \\
\hline $\mathrm{SO}_{4}^{2-}$ & $1.73 \mathrm{e}+1$ & 1.73 & $1.80 e-4$ & $3.35 e-1$ & $-3.60 e-4$ \\
\hline $\mathrm{XH}_{2} \mathrm{O}$ & $43.635 \%$ & $4.36 e+1$ & & & \\
\hline \multicolumn{2}{|c|}{ mass balance $x$} & 97.75 & \multicolumn{2}{|c|}{$\begin{array}{c}\text { minus:plus charge } \\
\text { rat fo }\end{array}$} & 1.28 \\
\hline
\end{tabular}

\begin{tabular}{|c|c|c|}
\hline \multirow[t]{2}{*}{ Compacted Sludge } & \multicolumn{2}{|c|}{ Total Dissolved Solids } \\
\hline & from Chemical & from Thermal \\
\hline $\begin{array}{l}\text { In-Plant } \\
\text { Ist Run }\end{array}$ & $24.35 \%$ & $24.03 \%$ \\
\hline $\begin{array}{l}\text { In-Plant } \\
\text { 2nd Run }\end{array}$ & $197.58 \%$ & $20.56 \%$ \\
\hline $\begin{array}{c}\text { Early In-Plant } \\
\text { Ist Run }\end{array}$ & $24.74 \%$ & $24.27 \%$ \\
\hline $\begin{array}{c}\text { Early In-Plant } \\
\text { 2nd Run }\end{array}$ & $26.95 \%$ & $25.64 \%$ \\
\hline $\begin{array}{l}\text { In-Farm } \\
\text { lst Run }\end{array}$ & $53.58 \%$ & $35.46 \%$ \\
\hline $\begin{array}{l}\text { In-Farm } \\
\text { 2nd Run }\end{array}$ & $41.38 \%$ & $34.73 \%$ \\
\hline
\end{tabular}




\begin{tabular}{|c|c|c|c|c|c|c|c|}
\hline \multirow{2}{*}{ Analyte } & \multirow{2}{*}{$\begin{array}{l}\text { Total } \\
\text { Moles }\end{array}$} & \multicolumn{3}{|c|}{ As Settled sludge } & \multicolumn{3}{|c|}{ Compacted Sludge } \\
\hline & & $\begin{array}{c}\text { Supernate } \\
\%\end{array}$ & $\begin{array}{c}\text { Sludge } \\
x\end{array}$ & $\begin{array}{c}\text { Total } \\
x\end{array}$ & $\begin{array}{c}\text { Supernate } \\
x\end{array}$ & 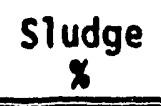 & $\begin{array}{c}\text { Total } \\
\times\end{array}$ \\
\hline Fe & 0.01996 & 0.222 & $88.3^{\prime}$ & $88.5^{\prime}$ & 0.261 & $89.5^{1}$ & $89.8^{\prime}$ \\
\hline K & 0.02 & 90.8 & $15.4^{\prime}$ & $106 . '$ & 107. & $\begin{array}{r}<0.25^{\prime} \\
3.33^{\prime}\end{array}$ & $\begin{array}{l}107.1 \\
110.1\end{array}$ \\
\hline $\mathrm{Na}$ & 3.919 & 85.8 & $14.6^{1}$ & 100.1 & 101. & $3.57^{\prime}$ & $104 . .^{\prime}$ \\
\hline Ni & 0.005 & 1.31 & $85.5^{\prime}$ & $86.8^{\prime}$ & 1.54 & $87.8^{\prime}$ & $89.3^{\prime}$ \\
\hline $\mathrm{CN}$ & 0.03 & 0.0963 & $105 .^{\circ}$ & $105 .^{d}$ & 0.113 & & \\
\hline $\mathrm{NH}_{3}$ & 0.05984 & 31.8 & & & 37.4 & $1.92^{1}$ & $39.3^{1}$ \\
\hline $\mathrm{NO}_{3}$ & 3.2736 & 87.1 & & & 102. & $3.49^{\prime}$ & 105.1 \\
\hline $\mathrm{PO}_{4}$ & 0.132 & 28.6 & & & 27.4 & $\begin{array}{l}5.70^{\prime} \\
3.13^{\prime} \\
\end{array}$ & $\begin{array}{l}33.1^{\prime} \\
30.5^{\prime}\end{array}$ \\
\hline $\mathrm{SO}_{4}$ & 0.06484 & 58.3 & & & 68.4 & $10.0^{1}$ & $78.4^{1}$ \\
\hline
\end{tabular}

Based on Ignition results.

1 Based on water leachate results.

dased on direct analysis results. 


\begin{tabular}{|c|c|c|c|c|c|c|}
\hline \multicolumn{2}{|c|}{ Table A-27. } & \multicolumn{2}{|c|}{ Supeinate } & \multicolumn{3}{|c|}{$R-9902$} \\
\hline \multicolumn{2}{|c|}{ PR-9902 Andiysts } & \multicolumn{5}{|c|}{ Converted to Supernate } \\
\hline analyte & $\begin{array}{l}\text { value } \\
\text { ng/L or } \\
\text { other }\end{array}$ & $\operatorname{mg} / g$ & weight $x$ & $\begin{array}{c}\text { moles/ } \\
\text { grain }\end{array}$ & $\begin{array}{l}\text { mole } \\
\text { ratio }\end{array}$ & $\begin{array}{l}\text { charge } \\
\text { equiv.l } \\
\text { gram }\end{array}$ \\
\hline Fé & 8.2 & $6.03 e-3$ & $6.03 e-4$ & $1.08 \mathrm{e}-7$ & 1. & $2.16 e-7$ \\
\hline$k$ & $834 \%$ & $5.40 e-1$ & $5.40 \mathrm{e}-2$ & $1.38 \mathrm{e}-5$ & $1.28 e+2$ & $1.38 e-5$ \\
\hline $\mathrm{Na}$ & 152000 & $1.12 \mathrm{e}+2$ & $1.12 e+1$ & $4.86 e-3$ & $4.50 \mathrm{e}+4$ & $4.86 e-3$ \\
\hline Ni & 0.244 & $1.79 e-4$ & $1.79 e-5$ & $3.06 \mathrm{e}-9$ & $2.83 e-2$ & $6.11 \mathrm{e}-9$ \\
\hline $\mathrm{CH}^{\circ}$ & 24.2 & $1.78 e-2$ & $1.78 \mathrm{e}-3$ & $6.84 e-7$ & 6.33 & $-6.84 e-7$ \\
\hline $\mathrm{Cl}^{\circ}$ & $<20$ & $\leqslant 0.0140$ & $<0.001$ & -- & - & - \\
\hline $\mathrm{NO}_{3}^{-}$ & 369000 & $2.7 ! e+2$ & $2.71 e+1$ & $9.38 e-3$ & $4.05 e+4$ & $-4.38 e-3$ \\
\hline $\mathrm{PO}_{2}^{3-}$ & $\therefore 3000$ & $1.69 e+2$ & 1.69 & $1.78 e-4$ & $1.65 \mathrm{e}+3$ & $-5.34 e-4$ \\
\hline $\mathrm{SO}_{\mathrm{h}}^{2-}$ & 39400 & $2.90 e+1$ & 2.90 & $3.02 e-4$ & $2.79 e+3$ & $-6.03 e-4$ \\
\hline $\mathrm{KH}_{2} \mathrm{O}$ & $55.4 x$ & & 55.4 & & & \\
\hline Sps & 1.36 & & & & & \\
\hline $\mathrm{pH}$ & 9.18 & & & & & \\
\hline \multicolumn{3}{|c|}{ mass balance $x$} & $98.35 \%$ & \multicolumn{2}{|c|}{$\begin{array}{l}\text { minus:plus charge } \\
\text { ratio }\end{array}$} & 1.13 \\
\hline
\end{tabular}

\begin{tabular}{|c|c|c|c|}
\hline \multicolumn{2}{|c|}{ Table A-38. } & $\begin{array}{c}\text { In-Farm 1st Run } \\
\text { CJ-83-A }\end{array}$ & $\begin{array}{c}\text { As Settled Sludge Direct } \mathrm{CN}^{-} \\
\mathrm{R}-9975\end{array}$ \\
\hline analyte & value & $\mathrm{mg} / \mathrm{g}$ & weight $x$ \\
\hline $\mathrm{CN}^{\circ}$ & $1.50 \mathrm{e}+4 \mu \mathrm{g} / \mathrm{g}$ & 15 & 1.50 \\
\hline
\end{tabular}


Table A-29. In-Farm 1st Run As Settled Sludge Chelate Dissolution CJ-79-F R-9988

\begin{tabular}{|c|c|c|c|c|c|c|}
\hline \multicolumn{2}{|c|}{ R-9988 Analysis } & \multicolumn{5}{|c|}{ Converted to As Settled Sludge } \\
\hline $\begin{array}{r}\text { analyte } \\
\\
\end{array}$ & $\begin{array}{l}\text { value } \\
\text { mg/L or } \\
\text { other }\end{array}$ & $\mathrm{mg} / \mathrm{g}$ & weight $x$ & $\begin{array}{c}\text { mole/ } \\
\text { gram }\end{array}$ & $\begin{array}{l}\text { mole } \\
\text { ratio }\end{array}$ & $\begin{array}{c}\text { charge } \\
\text { equiv./ } \\
\text { gram }\end{array}$ \\
\hline $\mathrm{Fe}$ & $6.23 \mathrm{e}+01$ & 6.00 & $6.00 \mathrm{e}-1$ & $1.07 e-4$ & 1. & $2.15 e-4$ \\
\hline $\mathbf{K}$ & $<1.02 e+01$ & & & & & \\
\hline $\mathrm{Na}$ & $2.230 \mathrm{e}+03$ & $1.26 e+2$ & $1.26 e+1$ & $5.49 e-3$ & $5.11 \mathrm{e}+1$ & $5.49 e-3$ \\
\hline Ni & $5.75 e+01$ & 5.53 & $5.53 e-1$ & $9.43 e-5$ & $8.78 e-1$ & $1.89 e-4$ \\
\hline $\mathrm{CN}^{-}$ & $1.46 \mathrm{e}+02$ & $1.41 \mathrm{e}+1$ & 1.41 & $5.40 e-4$ & 5.03 & $-5.40 \mathrm{e}-4$ \\
\hline $\mathrm{Cl}^{\circ}$ & $3.096 \mathrm{e}+01$ & 2.98 & $2.98 e-1$ & $8.40 e-5$ & $7.83 e-1$ & $-8.40 e-5$ \\
\hline $\mathrm{NO}_{3}^{-}$ & $2.820 \mathrm{e}+03$ & $2.71 e+2$ & $2.71 \mathrm{e}+1$ & $4.38 e-3$ & $4.08 \mathrm{e}+1$ & $-4.38 e-3$ \\
\hline $\mathrm{PO}_{2}^{3-}$ & $1.95 \mathrm{e}+02$ & $1.88 e+1$ & 1.88 & $1.98 e-4$ & 1.84 & $-5.93 e-4$ \\
\hline $\mathrm{SO}_{2}^{2-}$ & $2.53 \mathrm{e}+02$ & $2.44 \mathrm{e}+1$ & 2.44 & $2.54 e-4$ & 2.36 & $-5.07 e-4$ \\
\hline$x_{2} \mathrm{H}_{2} \mathrm{O}$ & $99.5 \%$ & & $\begin{array}{l}53.7 \\
\text { (fr. TGA) }\end{array}$ & & & \\
\hline Spg & 0.989 & & & & & \\
\hline $\mathrm{pH}$ & 10.3 & & & & & \\
\hline & ss balanc & & 100.57 & $\begin{array}{r}\text { minus:pl } \\
\text { rat }\end{array}$ & charge & 1.04 \\
\hline
\end{tabular}

" $919.6 \mathrm{mg} / \mathrm{L} \mathrm{Na}$ contributed by EDTA subtracted out. 
Table A-30. In-Farm 1st Run Compacted Sludge Chelate Dissolution CJ-91-A R-15

\begin{tabular}{|c|c|c|c|c|c|c|}
\hline \multicolumn{2}{|c|}{ \#R-15 Analytical Data } & \multicolumn{5}{|c|}{ Converted to Compacted Sludge } \\
\hline analyte & value & $\mathrm{mg} / \mathrm{g}$ & $\underset{x}{\text { weight }}$ & $\begin{array}{c}\text { mole/ } \\
\text { gram }\end{array}$ & $\begin{array}{l}\text { mole } \\
\text { ratio }\end{array}$ & $\begin{array}{l}\text { charge } \\
\text { equiv.l } \\
\text { gram }\end{array}$ \\
\hline $\mathrm{Fe}$ & $7.932 \mathrm{e}-03 \mathrm{M}$ & $2.91 e+1$ & 2.91 & $5.21 e-4$ & 1. & $1.04 e-3$ \\
\hline$k$ & $3.260 \mathrm{e}-04 M$ & $8.38 e-1$ & $8.38 e-2$ & $2.14 e-5$ & $4.11 e-2$ & $2.14 e-5$ \\
\hline $\mathrm{Na}$ & $4.730 \mathrm{e}-01 \mathrm{~N}$ & $4.73 e+2^{1}$ & $4.73 e+1$ & $2.06 e-2$ & $3.95 e+1$ & $2.06 e-2$ \\
\hline $\mathrm{Ni}$ & $7.440 \mathrm{e}-03 \mathrm{M}$ & $2.87 e+1$ & 2.87 & $4.89 e-4$ & $9.38 \mathrm{e}-1$ & $9.78 \mathrm{e}-4$ \\
\hline $\mathrm{CN}^{-}$ & $1.198 \mathrm{e}+03 \mathrm{mg} / \mathrm{L}$ & $7.87 e+1$ & 7.87 & $3.03 e-3$ & 5.81 & $-3.03 e-3$ \\
\hline $\mathrm{Cl}^{\circ}$ & $7.940 \mathrm{e}+01 \mathrm{mg} / \mathrm{L}$ & 5.22 & $5.22 \mathrm{e}-1$ & $1.47 \mathrm{e}-4$ & $2.82 e-1$ & $-1.47 e-4$ \\
\hline $\mathrm{NO}_{3}^{-}$ & masked $^{2}$ & -200 & -20 & $3.23 e-3$ & 6.19 & $-3.23 e-3$ \\
\hline $\mathrm{PO}_{4}^{3-}$ & $2.800 \mathrm{e}+02 \mathrm{mg} / \mathrm{L}$ & $1.84 \mathrm{e}+1$ & 1.84 & $1.94 e-4$ & $3.72 e-1$ & $-5.82 e-4$ \\
\hline $\mathrm{SO}_{2}^{2-}$ & $2.680 \mathrm{e}+02 \mathrm{mg} / \mathrm{L}$ & $1.76 \mathrm{e}+1$ & 1.76 & $1.83 e-4$ & $3.52 \mathrm{e}-1$ & $-3.67 e-4$ \\
\hline$\% \mathrm{H}_{2} \mathrm{O}$ & $98.33 \%$ & & $\begin{array}{r}4.24 e+1 \\
(\mathrm{fr} . \mathrm{TGA}) \\
\end{array}$ & & & \\
\hline SpG & 0.998 & & & & & \\
\hline $\mathrm{pH}$ & 10.88 & & & & & \\
\hline \multicolumn{3}{|c|}{ mass bålance $\%$} & 127.53 & \multicolumn{2}{|c|}{$\begin{array}{c}\text { minus: plus charge } \\
\text { ratio }\end{array}$} & $3.25 e-1$ \\
\hline
\end{tabular}

'The $\mathrm{Na}$ contributed by EDTA subtracted out.

${ }^{2}$ The nitrate value was masked by the large EDTA peak. The value given is estimated

from the water leach of compacted sludge. 
Table A-31. In-Farm 1st Run Water Leachate of Compacted Sludge CJ-91-B R-16

\begin{tabular}{|c|c|c|c|c|}
\hline \multicolumn{3}{|c|}{ R-16 Analytical Data } & \multicolumn{2}{|c|}{$\begin{array}{c}\text { Converted to Compacted } \\
\text { Sludge }\end{array}$} \\
\hline analyte & value & $\begin{array}{l}\text { weight } x \\
\text { sample }\end{array}$ & $m g / g$ & $\begin{array}{c}\text { \% of } \\
\text { compacted } \\
\text { sludge }\end{array}$ \\
\hline $\mathrm{Fe}$ & $5.64 e-5 M$ & $3.18 e-4$ & $1.00 \mathrm{e}-1$ & $1.00 \mathrm{e}-2$ \\
\hline$k$ & $2.64 e-4 M$ & $1.04 \mathrm{e}-3$ & $3.28 e-1$ & $3.28 \mathrm{Be}-2$ \\
\hline $\mathrm{Na}$ & $3.86 \mathrm{e}-1 \mathrm{H}$ & $8.95 e-1$ & $2.81 e+2$ & $2.81 \mathrm{e}+1$ \\
\hline $\mathrm{NI}$ & $1.64 \mathrm{e}-5 \mathrm{H}$ & $9.72 e-5$ & $3.06 e-2$ & $3.06 e-3$ \\
\hline $\mathrm{CN}^{-}$ & $7.59 \mathrm{mg} / \mathrm{L}$ & $7.66 e-4$ & $2.41 \mathrm{e}-1$ & $2.41 \mathrm{e}-2$ \\
\hline $\mathrm{Cl}^{\circ}$ & $1.03 \mathrm{e}+2 \mathrm{mg} / \mathrm{L}$ & $1.04 \mathrm{e}-2$ & 3.27 & $3.27 e-1$ \\
\hline $\mathrm{NO}_{3}^{\circ}$ & $6.35 \mathrm{e}+3 \mathrm{mg} / \mathrm{L}$ & $6.41 \mathrm{e}-1$ & $2.02 \mathrm{e}+2$ & $2.02 e+1$ \\
\hline $\mathrm{PO}_{h}^{3-}$ & $4.89 \mathrm{e}+2 \mathrm{mg} / \mathrm{L}$ & $4.93 e-2$ & $1.55 \mathrm{e}+1$ & 1.55 \\
\hline $\mathrm{SO}_{2}^{2-}$ & $1.05 \mathrm{e}+3 \mathrm{mg} / \mathrm{L}$ & $1.06 e-1$ & $3.33 \mathrm{e}+1$ & 3.33 \\
\hline $\mathrm{XH}_{2} \mathrm{O}$ & $99.48 \%$ & $9.95 \mathrm{e}+1$ & & \\
\hline SpG & 0.991 & & & \\
\hline $\mathrm{pH}$ & 10.15 & - & & \\
\hline \multicolumn{2}{|c|}{ mass balance $x$} & 101.18 & $\begin{array}{l}\text { total } \\
\text { soluble } \%\end{array}$ & 53.58 \\
\hline
\end{tabular}

Table A-32. In-Farm 1st Run X-ray Diffraction \& X-ray Florescence CJ-103-A IR-595

\begin{tabular}{|c|l|}
\hline Technique & \multicolumn{1}{|c|}{ Findings } \\
\hline$X R D$ & unable to identify any specific compound \\
\hline$X R F$ & $\begin{array}{l}\text { major }-\mathrm{Fe}, \mathrm{Ni} \\
\text { minor to trace }-\mathrm{Zn}, \mathrm{Ca}, \mathrm{K}, \mathrm{P}\end{array}$ \\
\hline
\end{tabular}




\begin{tabular}{|c|c|c|c|c|c|c|c|}
\hline \multirow{2}{*}{ Analyte } & \multirow{2}{*}{$\begin{array}{l}\text { Total } \\
\text { Moles }\end{array}$} & \multicolumn{3}{|c|}{ As Settled Sludge } & \multicolumn{3}{|c|}{ Compacted Sludge } \\
\hline & & Supernate & $\underset{x}{\text { Sludge }}$ & $\begin{array}{c}\text { Total } \\
x\end{array}$ & $\begin{array}{c}\text { Supernate } \\
x\end{array}$ & $\begin{array}{c}\text { Sludge } \\
x\end{array}$ & $\begin{array}{c}\text { Total } \\
x\end{array}$ \\
\hline $\mathrm{Fe}$ & 0.00498 & 2.82 & $122^{\circ}$ & $125^{c}$ & 2.92 & $95.0^{c}$ & $97.9^{c}$ \\
\hline$k$ & 0.01992 & 90.1 & & & 93.4 & $\begin{array}{l}0.98^{c} \\
0.34^{1} \\
\end{array}$ & $\begin{array}{l}94.4^{c} \\
93.7^{1} \\
\end{array}$ \\
\hline $\mathrm{Na}$ & 7.40025 & 85.4 & $4.21^{c}$ & $89.6^{c}$ & 88.5 & $\begin{array}{l}2.52^{\mathrm{c}} \\
1.50^{1}\end{array}$ & $\begin{array}{l}91.0^{c} \\
90.0^{1}\end{array}$ \\
\hline $\mathrm{Ni}$ & 0.005 & 0.0796 & $107 .{ }^{c}$ & $107 .^{c}$ & 0.0825 & $88.8^{c}$ & $88.9^{c}$ \\
\hline $\mathrm{CN}$ & 0.02988 & 2.98 & $\begin{array}{l}102 . \stackrel{\mathrm{d}}{ } \\
109 .\end{array}$ & $\begin{array}{l}105 . \\
110^{\prime}\end{array}$ & 3.09 & $92.1^{c}$ & $95.2^{c}$ \\
\hline $\mathrm{Cl}$ & 0.019734 & $<2.6$ & $24.1^{c}$ & $<26.7^{c}$ & $<2.70$ & $\begin{array}{l}6.76^{c} \\
4.25^{1} \\
\end{array}$ & $\begin{array}{l}<9.46^{c} \\
<6.95^{1} \\
\end{array}$ \\
\hline $\mathrm{NO}_{3}$ & 6.166875 & 92.3 & $4.03^{e}$ & $96.3^{c}$ & 95.7 & $0.48^{\prime}$ & $96.2^{1}$ \\
\hline $\mathrm{PO}_{4}$ & 0.246675 & 93.8 & $4.55^{c}$ & $98.4^{c}$ & 97.3 & $\begin{array}{l}0.71^{c} \\
0.60^{\prime}\end{array}$ & $\begin{array}{l}98.0^{c} \\
97.9^{1} \\
\end{array}$ \\
\hline $\mathrm{SO}_{4}$ & 0.350345 & 112 & $4.11^{c}$ & $116^{c}$ & 116 & $\begin{array}{l}0.47^{c} \\
0.90^{l} \\
\end{array}$ & $117.6^{c}$ \\
\hline
\end{tabular}

1 Based on water leachate results.

- Based on direct analysis results.

c Based on chelate dissolution results. 
WHC-EP-0635

Table A-34. In-Farm 2nd Run Supernate CJ-93-A R-601

RR-601 Analysis

Converted to Supernate

\begin{tabular}{|c|c|c|c|c|c|c|}
\hline analyte & $\begin{array}{l}\text { value } \\
\text { ng/L or } \\
\text { other }\end{array}$ & $\mathrm{mg} / \mathrm{g}$ & weight $x$ & $\begin{array}{c}\text { moles/ } \\
\text { gram }\end{array}$ & $\begin{array}{l}\text { mole } \\
\text { ratio }\end{array}$ & $\begin{array}{c}\text { charge } \\
\text { equiv./ } \\
\text { gram }\end{array}$ \\
\hline $\mathrm{Fe}$ & 26.1 & $1.92 e-2$ & $1.92 e-3$ & $3.44 e-7$ & 1. & $6.88 e-7$ \\
\hline$K$ & 874 & $6.43 e-1$ & $6.43 e-2$ & $1.64 e-5$ & $4.78 e+1$ & $1.64 e-5$ \\
\hline $\mathrm{Na}$ & $1.86 e+5$ & $1.37 e+2$ & $1.37 e+1$ & $5.95 e-3$ & $1.73 e+4$ & $5.95 e-3$ \\
\hline $\mathrm{Ni}$ & 4.24 & $3.12 e-3$ & $3.12 e-4$ & $5.31 e-8$ & $1.55 e-1$ & $1.06 e-7$ \\
\hline $\mathrm{CN}^{\circ}$ & 62.2 & $4.57 e-2$ & $4.57 e-3$ & $1.76 e-6$ & 5.12 & $-1.76 e-6$ \\
\hline $\mathrm{Cl}^{-}$ & 1260 & $9.26 e-1$ & $9.26 e-2$ & $2.61 e-5$ & $7.60 \mathrm{e}+1$ & $-2.61 e-5$ \\
\hline $\mathrm{NO}_{3}^{-}$ & $4.17 e+5$ & $3.07 \mathrm{e}+2$ & $3.07 e+1$ & $4.95 e-3$ & $1.44 e+4$ & $-4.95 e-3$ \\
\hline $\mathrm{PO}_{1}^{3-}$ & $2.11 e+4$ & $1.55 \mathrm{e}+1$ & 1.55 & $1.63 e-4$ & $4.75 e+2$ & $-4.90 e-4$ \\
\hline $\mathrm{SO}_{2}{ }^{2-}$ & $3.07 e+4$ & $2.26 e+1$ & 2.26 & $2.35 e-4$ & $6.84 e+2$ & $-4.70 e-4$ \\
\hline $\mathscr{x}_{2} \mathrm{O}$ & $55.65 \%$ & & $5.57 e+1$ & & & \\
\hline SpG & 1.36 & & & & & \\
\hline $\mathrm{pH}$ & 9.69 & & & & & \\
\hline \multicolumn{3}{|c|}{ mass balance $x$} & 104.07 & \multicolumn{2}{|c|}{$\begin{array}{c}\text { minus : pius charge } \\
\text { rat io }\end{array}$} & 0.994 \\
\hline
\end{tabular}

Table A-35. In-Farm 2nd Run As Settled Sludge Direct $\mathrm{CN}^{-}$

$$
\text { CJ-93-B R-612 }
$$

\begin{tabular}{|c|c|c|c|}
\hline analyte & value & $\mathrm{mg} / \mathrm{g}$ & weight $\%$ \\
\hline $\mathrm{CN}^{-}$ & $7460 \mu \mathrm{g} / \mathrm{g}$ & 7.46 & 0.75 \\
\hline
\end{tabular}


Table A-36. In-Farm 2nd Run Compacted Sludge Chelate Dissolution CJ-94-B IR-602

\begin{tabular}{|c|c|c|c|c|c|c|}
\hline \multicolumn{2}{|c|}{ R-602 Analysis } & \multicolumn{5}{|c|}{ Converted to compacted sludge } \\
\hline analyte & $\begin{array}{l}\text { value } \mathrm{mg} / \mathrm{L} \\
\text { or other }\end{array}$ & $\mathrm{mg} / \mathrm{g}$ & weight $x$ & $\begin{array}{l}\text { moles/ } \\
\text { gram }\end{array}$ & $\begin{array}{l}\text { mole } \\
\text { ratio }\end{array}$ & $\begin{array}{c}\text { charge } \\
\text { equiv./ } \\
\text { gram }\end{array}$ \\
\hline $\mathrm{Fe}$ & 459 & $3.09 e+1$ & 3.09 & $5.53 e-4$ & 1. & $1.11 \mathrm{e}-3$ \\
\hline $\mathbf{k}$ & 25.7 & 1.73 & $1.73 e-1$ & $4.43 e-5$ & $8.00 \mathrm{e}-2$ & $4.43 e-5$ \\
\hline $\mathrm{Na}$ & 3140 & $1.19 \mathrm{e}+2^{1}$ & $1.19 e+1$ & $5.16 e-3$ & 9.32 & $5.16 e-3$ \\
\hline $\mathrm{Ni}$ & 496 & $3.34 e+1$ & 3.34 & $5.69 e-4$ & 1.03 & $1.14 e-3$ \\
\hline $\mathrm{CN}^{\circ}$ & 1200 & $8.08 e+1$ & 8.08 & $3.11 e-3$ & 5.61 & $-3.11 e-3$ \\
\hline $\mathrm{Cl}^{-}$ & 60.6 & 4.08 & $4.08 e-1$ & $1.15 e-4$ & $2.08 e-1$ & $-1.15 e-4$ \\
\hline $\mathrm{NO}_{3}^{-}$ & 3560 & $2.40 \mathrm{e}+2$ & $2.40 e+1$ & $3.87 e-3$ & 6.99 & $-3.87 e-3$ \\
\hline $\mathrm{PO}_{4}^{3-}$ & 273 & $1.84 e+1$ & 1.84 & $1.94 e-4$ & $3.50 e-1$ & $-5.81 e-4$ \\
\hline $\mathrm{SO}_{4}{ }^{2-}$ & 252 & $1.70 \mathrm{e}+1$ & 1.70 & $1.77 \mathrm{e}-4$ & $3.19 e-1$ & $-3.53 e-4$ \\
\hline $\mathrm{XH}_{2} \mathrm{O}$ & $99.22 \%$ & & $\begin{array}{r}4.49 e+1 \\
\text { (fr. TGA) } \\
\end{array}$ & & & \\
\hline SpG & 0.889 & & & & & \\
\hline $\mathrm{pH}$ & 10.5 & & & & & \\
\hline \multicolumn{3}{|c|}{ mass balance $\%$} & 99.43 & \multicolumn{2}{|c|}{$\begin{array}{c}\text { minus: plus charge } \\
\text { rat io }\end{array}$} & 1.07 \\
\hline
\end{tabular}

'The $1379.4 \mathrm{mg} / \mathrm{L} \mathrm{Na}$ contributed from EDTA subtracted out. 
WHC-EP-0635

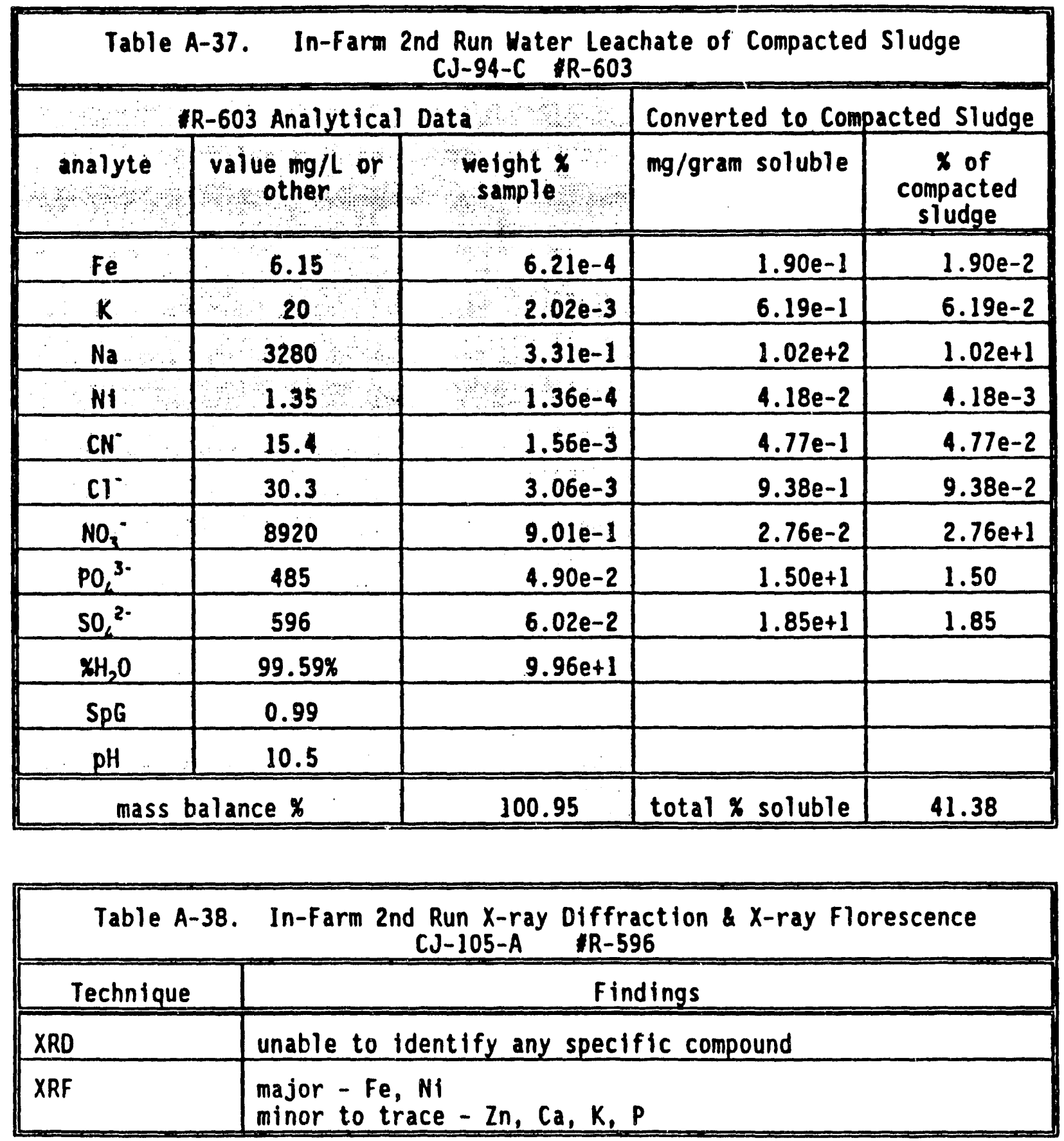




\begin{tabular}{|c|c|c|c|c|c|c|c|}
\hline \multirow{2}{*}{ Analyte } & \multirow{2}{*}{$\begin{array}{l}\text { Total } \\
\text { Moles }\end{array}$} & \multicolumn{3}{|c|}{ As Settled sludge } & \multicolumn{3}{|c|}{ Compacted Sludge } \\
\hline & & $\begin{array}{c}\text { Supernate } \\
x\end{array}$ & $\begin{array}{c}\text { Sludge } \\
\times\end{array}$ & $\begin{array}{c}\text { Total } \\
x\end{array}$ & $\begin{array}{c}\text { Supernate } \\
\times\end{array}$ & $\begin{array}{c}\text { Sludge } \\
\times\end{array}$ & $\begin{array}{c}\text { Total } \\
x\end{array}$ \\
\hline $\mathrm{Fe}$ & 0.00498 & 9.19 & & & 9.45 & $99.5^{c}$ & $109 .{ }^{\circ}$ \\
\hline$k$ & 0.01992 & 110 & & & 113. & $\begin{array}{l}1.99^{\mathrm{c}} \\
0.712^{1}\end{array}$ & $\begin{array}{l}115 .{ }^{\circ} \\
114.1\end{array}$ \\
\hline $\mathrm{Na}$ & 7.40025 & 107 & & & 110. & $\begin{array}{l}0.63^{c} \\
0.54^{1} \\
\end{array}$ & $\begin{array}{l}111 . \\
111 .\end{array}$ \\
\hline $\mathrm{Mi}$ & 0.005 & 0.0888 & & & 1.45 & $102 .^{c}$ & $103 .^{c}$ \\
\hline $\mathrm{CN}$ & 0.02988 & 7.84 & $44.2^{d}$ & $52.0^{d}$ & 8.05 & $93.3^{c}$ & $101^{c}$ \\
\hline Cl & 0.019734 & 176. & & & 181. & $\begin{array}{l}5.22^{c} \\
1.20^{\prime} \\
\end{array}$ & $\begin{array}{l}186 . .^{\circ} \\
182 .{ }^{\circ} \\
\end{array}$ \\
\hline $\mathrm{NO}_{3}$ & 6.166875 & 107. & & & 110. & $\begin{array}{l}0.56^{c} \\
6 . e-5^{1} \\
\end{array}$ & $\begin{array}{l}111 .^{\circ} \\
110 .\end{array}$ \\
\hline $\mathrm{PO}_{4}$ & $0.246675 \mid$ & 87.9 & & & 90.4 & $\begin{array}{l}0.71^{c} \\
0.57^{1} \\
\end{array}$ & $\begin{array}{l}91.1^{c} \\
91.0^{1} \\
\end{array}$ \\
\hline $\mathrm{SO}_{4}$ & 0.350345 & 89.2 & & & 91.7 & $\begin{array}{l}0.45^{c} \\
0.49^{1} \\
\end{array}$ & $\begin{array}{l}92.2^{c} \\
92.2^{1}\end{array}$ \\
\hline
\end{tabular}

1 Based on water leachate results.

d Based on direct analysis results.

c Based on chelate dissolution results. 
WHC-EP-0635

Figure 6.4. Correlation of Exotherms with Cyanide

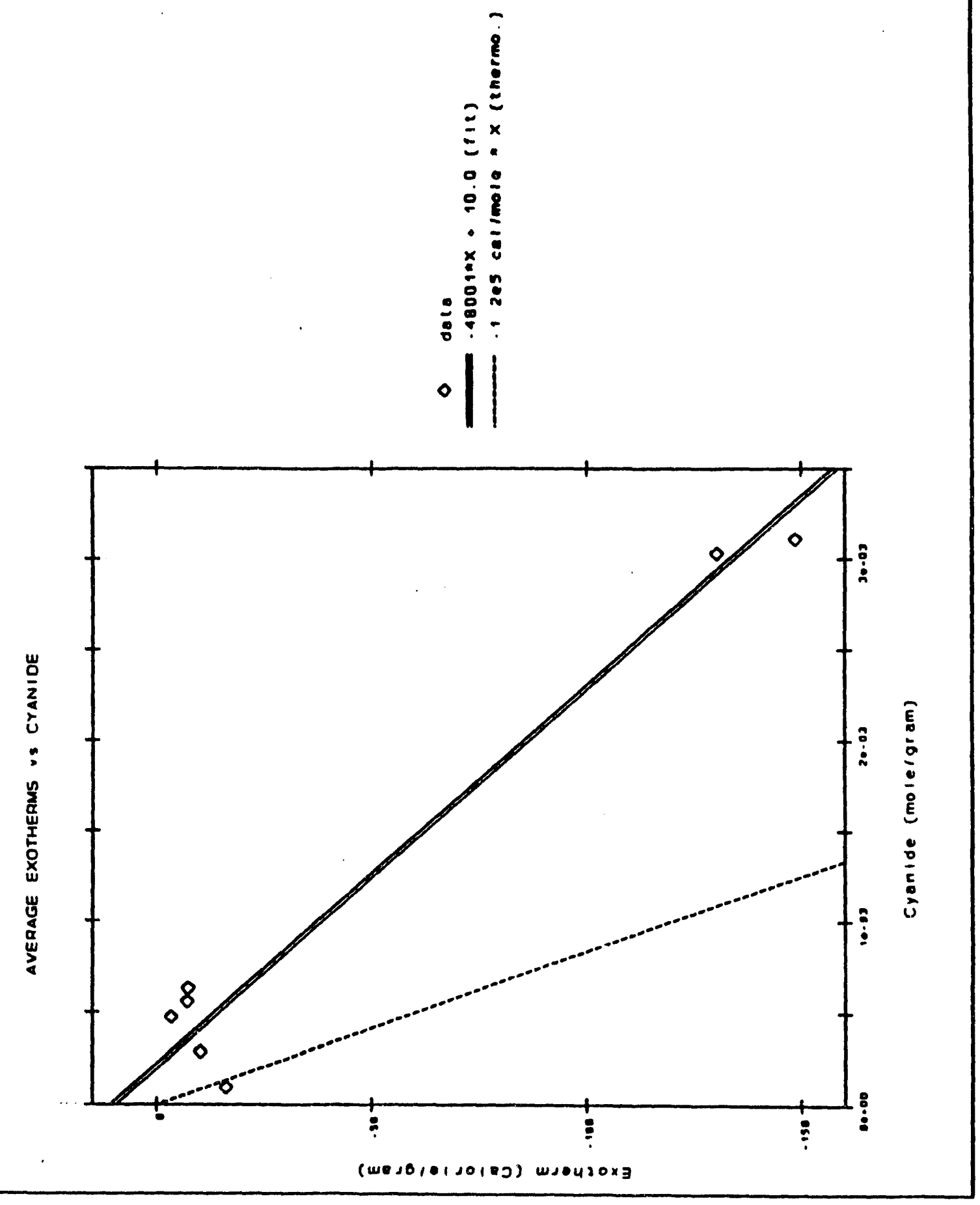


WHC-EP-0635

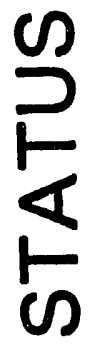

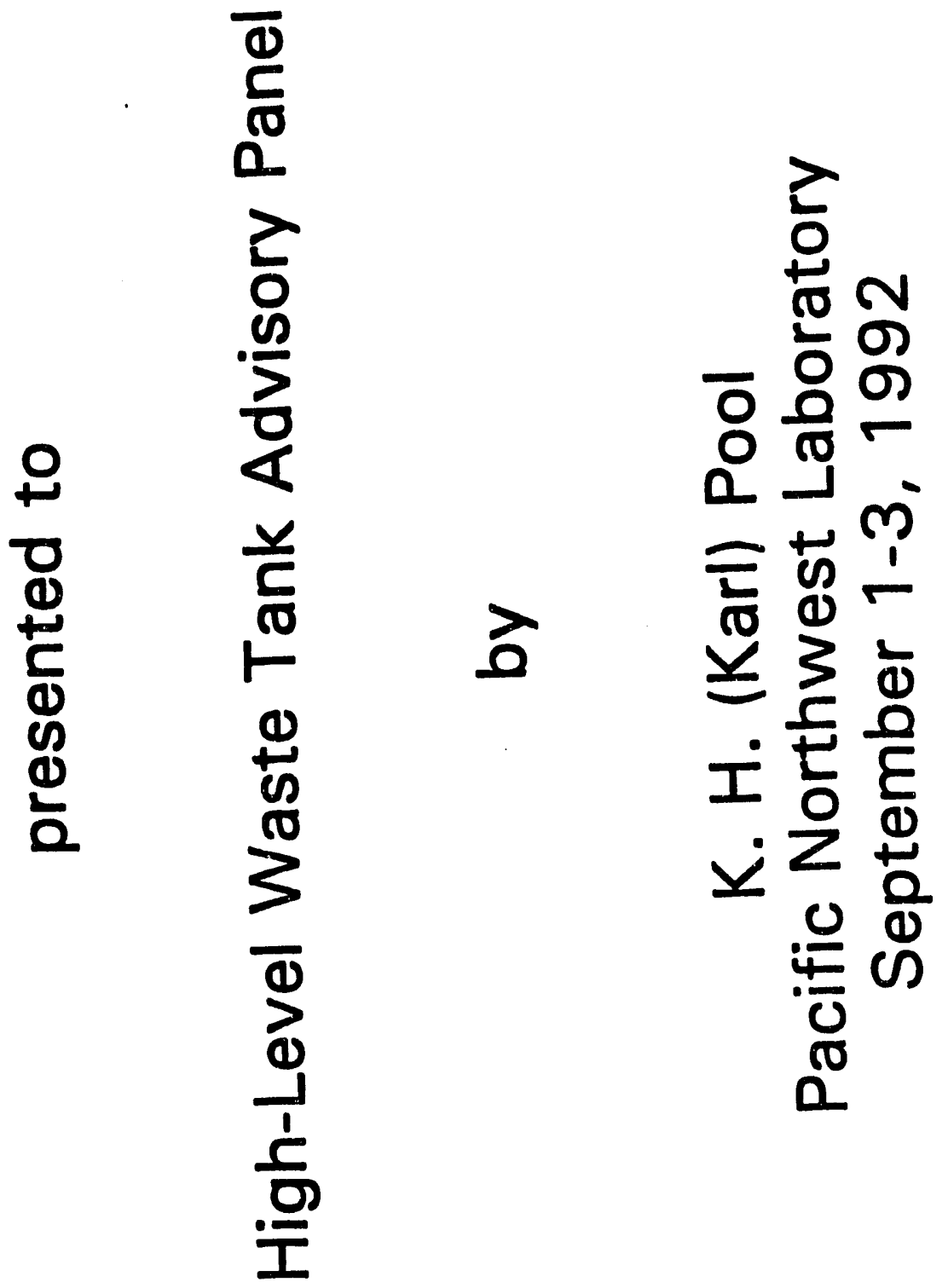


WHC-EP-0635

O

$\stackrel{\text { 山 }}{\mathrm{O}}$

\%

峲

$\stackrel{ }{\leftarrow}$

口

U

品

亏

O

崩

$\omega$

山

()

$>$

$\frac{3}{4}$

山

口

这

㐫

ฉृ

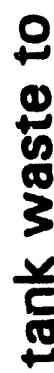

용

空

돌

త

.

霖 喜

을

통음드

ร 등

이

ङ은

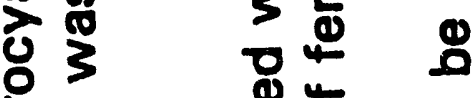

는. 드

4

ᄂ

돈

\%

Nㅗㄴ

온

ชิ

ॠ

兵

\&

Фㄴำ

훙을

ญ

号

ᄂ

ᄃ

象

응

車

兽 $\frac{0}{0}$ 员

잉 总

욤들

辰 융

음

Ð

永.

홍 은

당 둥

गे

E

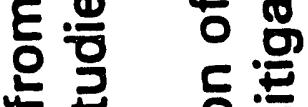

은 总

응 웅

空

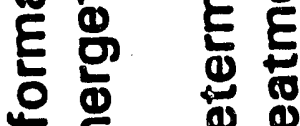

结 帘 
WHC-EP-0635

\section{IABLE 1}

\section{CYANIDE ANALYTICAL METHODS UNDER DE'JELOPMENT}

\begin{tabular}{|l|l|l|l|}
\hline $\begin{array}{l}\text { Sample } \\
\text { Matrix }\end{array}$ & $\begin{array}{l}\text { Sample } \\
\text { Preparation } \\
\text { Options }\end{array}$ & $\begin{array}{l}\text { Analytical } \\
\text { Method } \\
\text { Options }\end{array}$ & Comments \\
\hline Supernate & $\begin{array}{l}\text { no } \\
\text { preparation }\end{array}$ & $\begin{array}{l}\text { (1) Distillation } \\
\text { (2) } \begin{array}{l}\text { IC } \\
\text { (3) Spectroscopy } \\
\text { solution }\end{array}\end{array}$ & $\begin{array}{l}\text { (1) } \mathrm{DL}<100 \mathrm{ppb} \\
\text { (2) } \mathrm{DL}<10 \mathrm{ppb} \\
\text { (3) } \mathrm{DL} 100 \mathrm{ppm}\end{array}$ \\
\hline Solid & $\begin{array}{l}\text { Complexant } \\
\text { Dissolution }\end{array}$ & $\begin{array}{l}\text { (1) Distillation } \\
\text { (2) IC } \\
\text { (3) Spectroscopy } \\
\text { solution }\end{array}$ & $\begin{array}{l}\text { (1) } \mathrm{DL}<10 \mathrm{ppm} \\
\text { (2) } \mathrm{DL}<1 \mathrm{ppm} \\
\text { (3) }<100 \mathrm{ppm}\end{array}$ \\
\hline Solid & $\begin{array}{l}\text { no } \\
\text { preparation }\end{array}$ & $\begin{array}{l}\text { (1) Distillation } \\
\text { (2) Spectroscopy } \\
\text { solid }\end{array}$ & $\begin{array}{l}\text { (1) } \mathrm{DL}<10 \mathrm{ppm} \\
\text { (2) } \mathrm{DL} \sim 1000 \mathrm{ppm}\end{array}$ \\
\hline
\end{tabular}


WHC-EP-0635

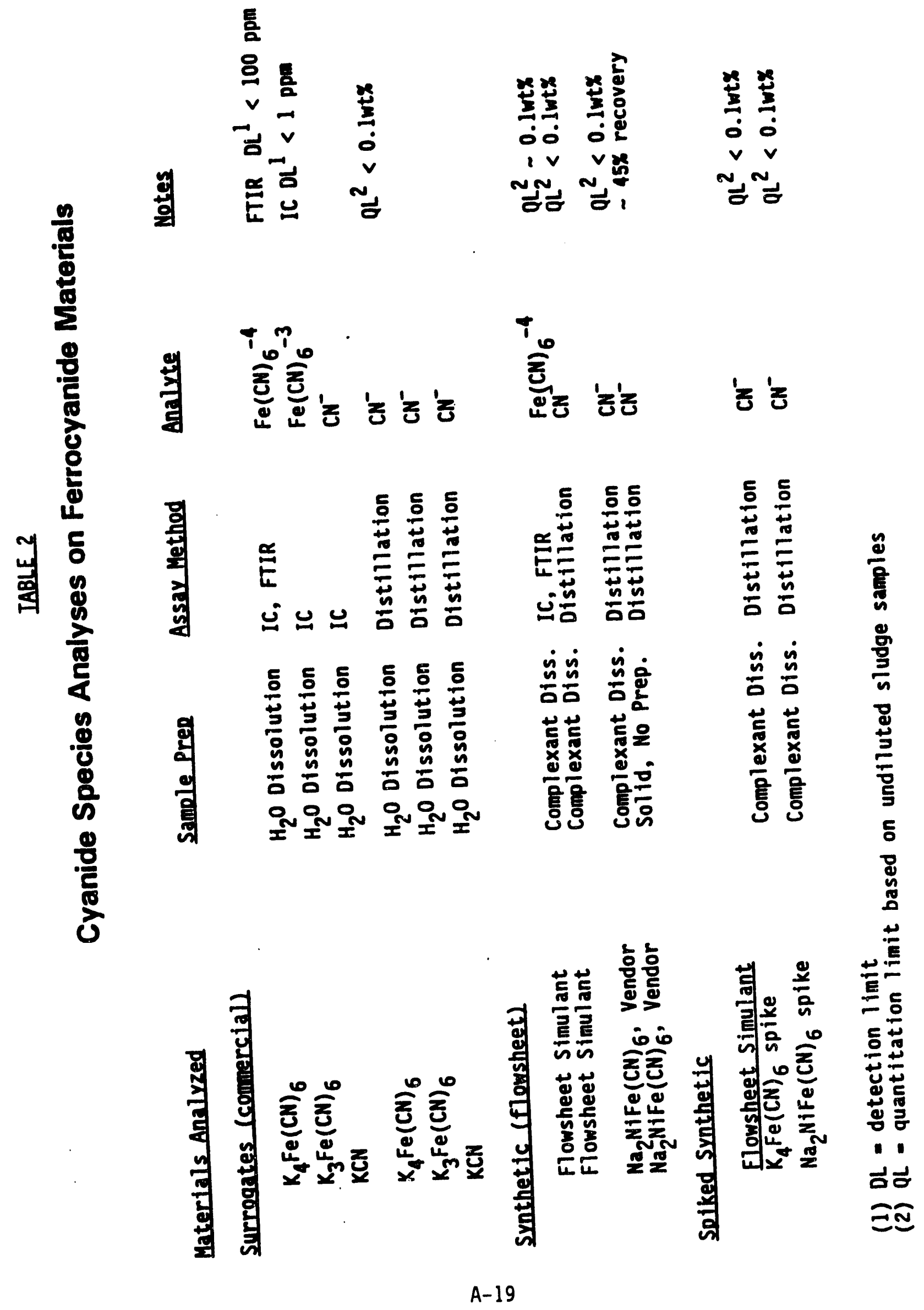


Solution FTIR Spectra of Cyanide Standards

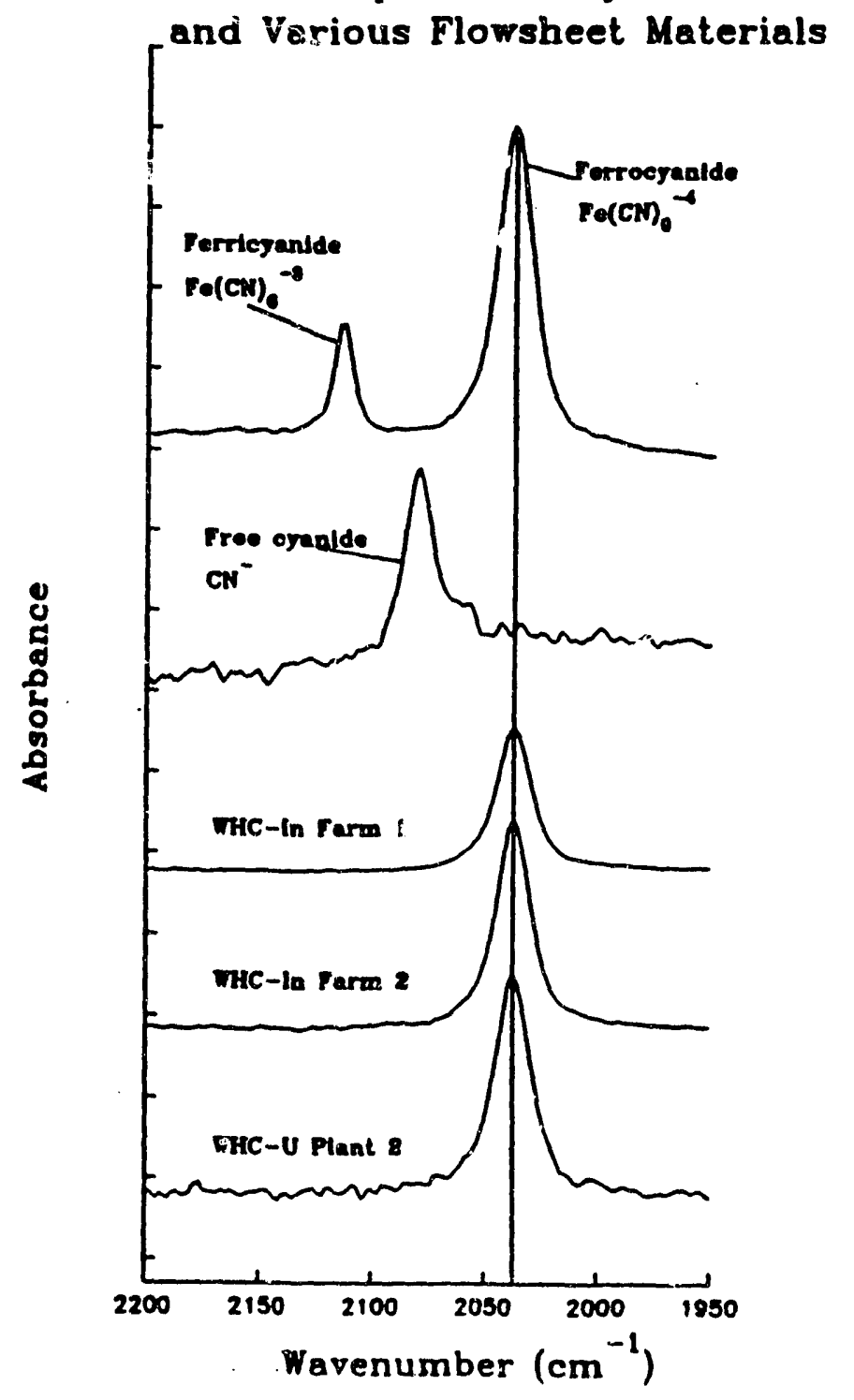


Typica! IC Chromatograms

Flowsheet Material Contains $\mathrm{Fe}(\mathrm{CN})_{6}{ }^{-4}$

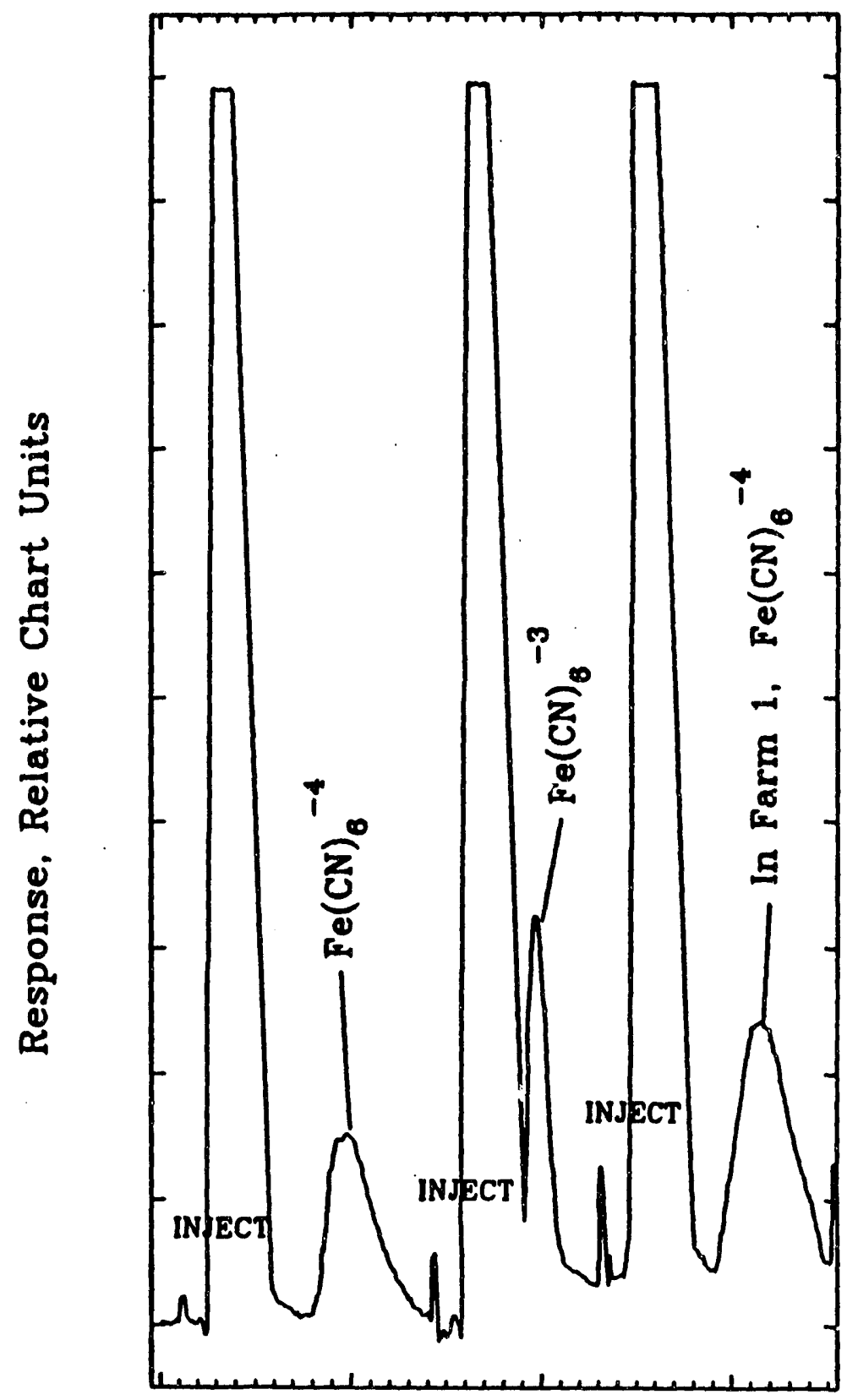

Time, Relative Chart Units 
WHC-EP-0635

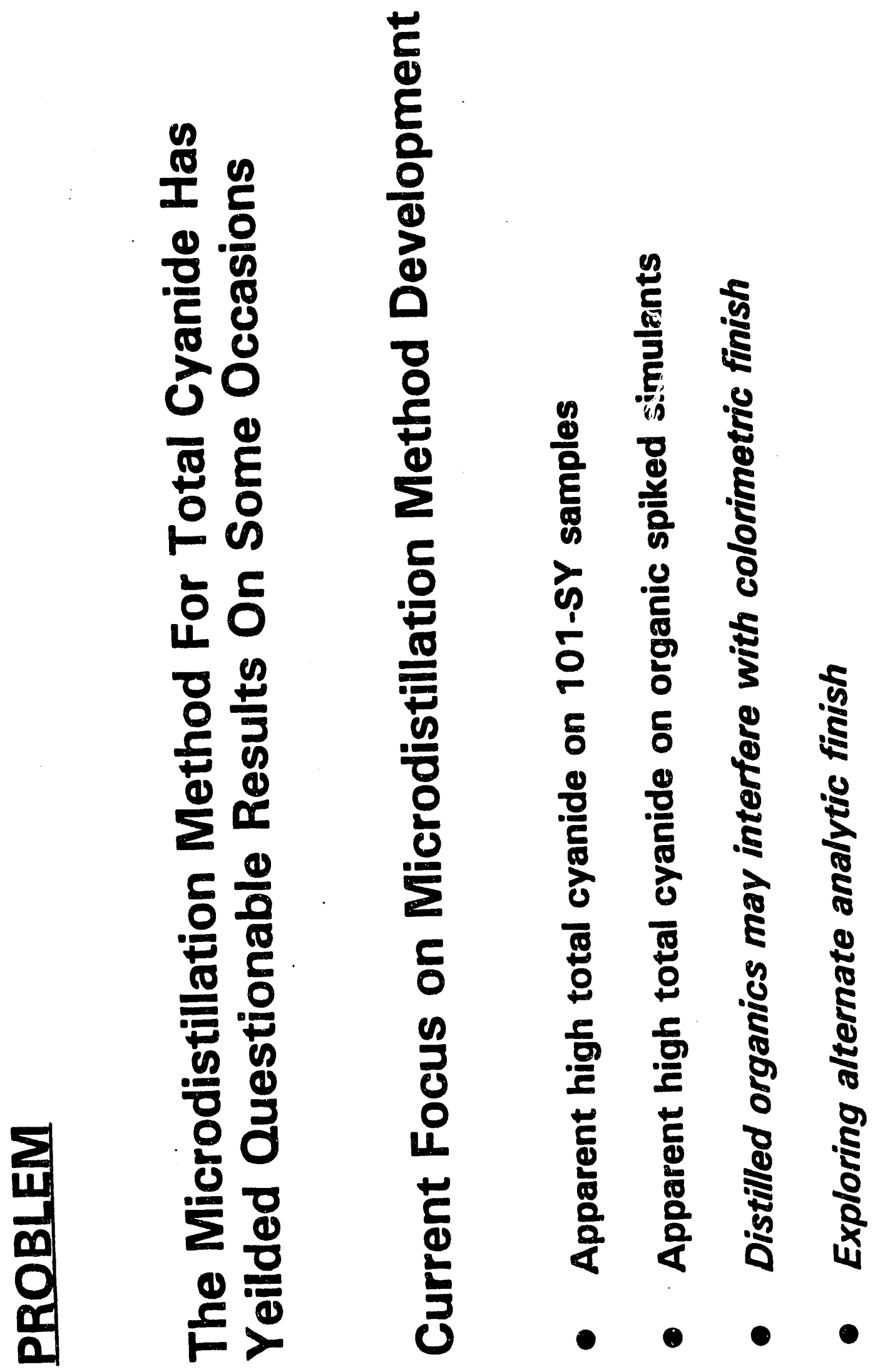


WHC-EP-0635

$\frac{8}{\frac{8}{8}}$

?

m
ญั.

햄

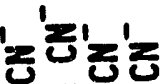

등흠틀음

옹음ำ

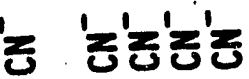

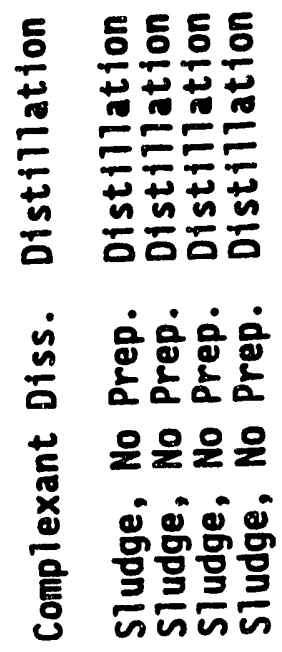

$\frac{0}{6}$

붑

혐

ㅎํำ

5

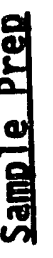

万

9

\%

2

5

的的是

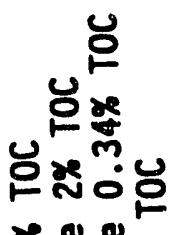

ส้ํํำ

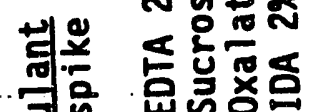

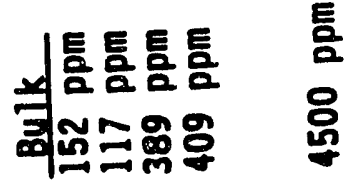
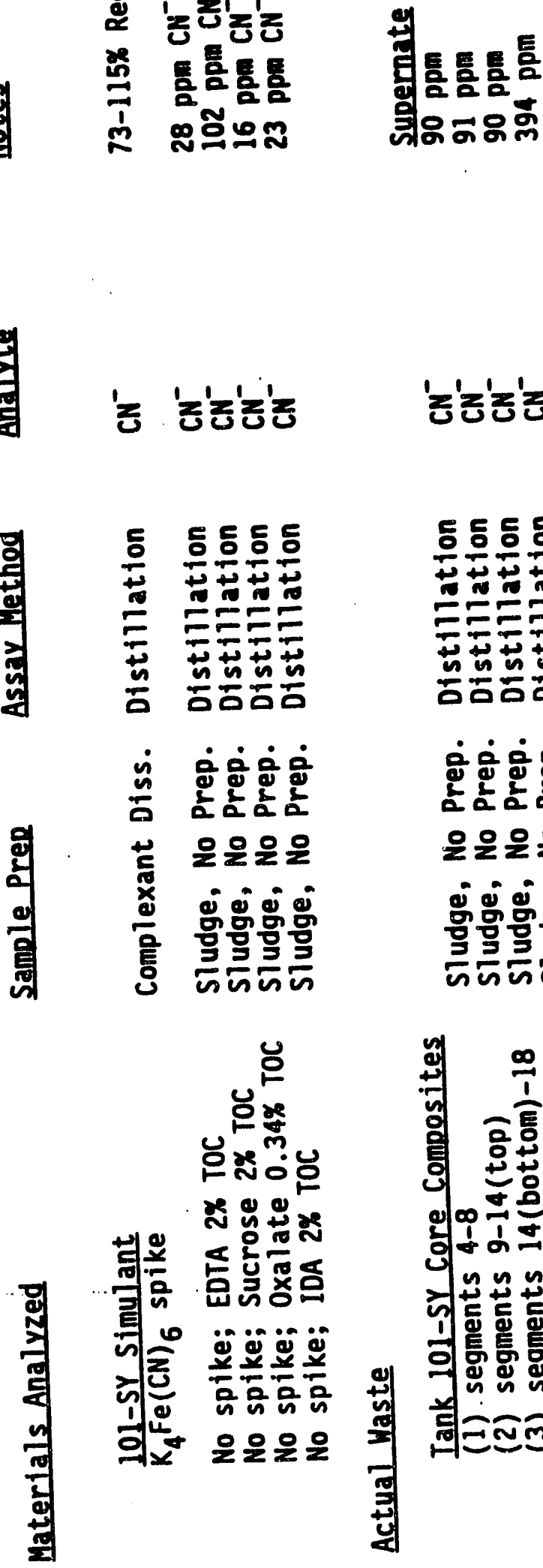

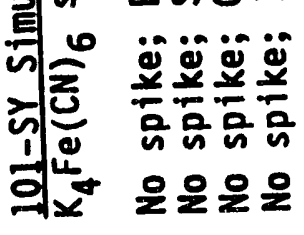

뷤

'전정정즌 '른

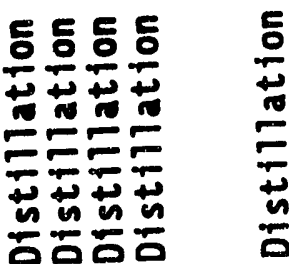

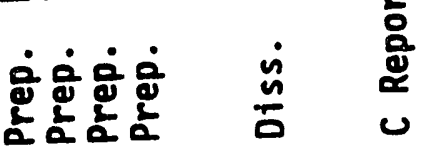

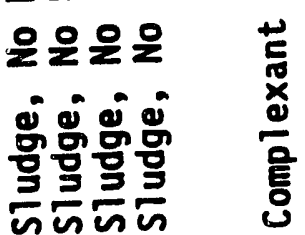

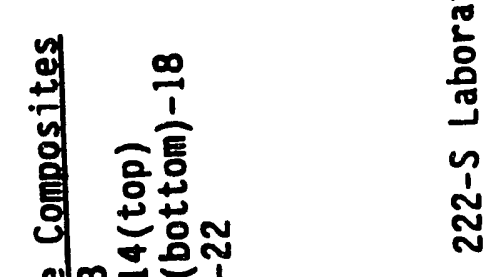


WHC-EP-0635
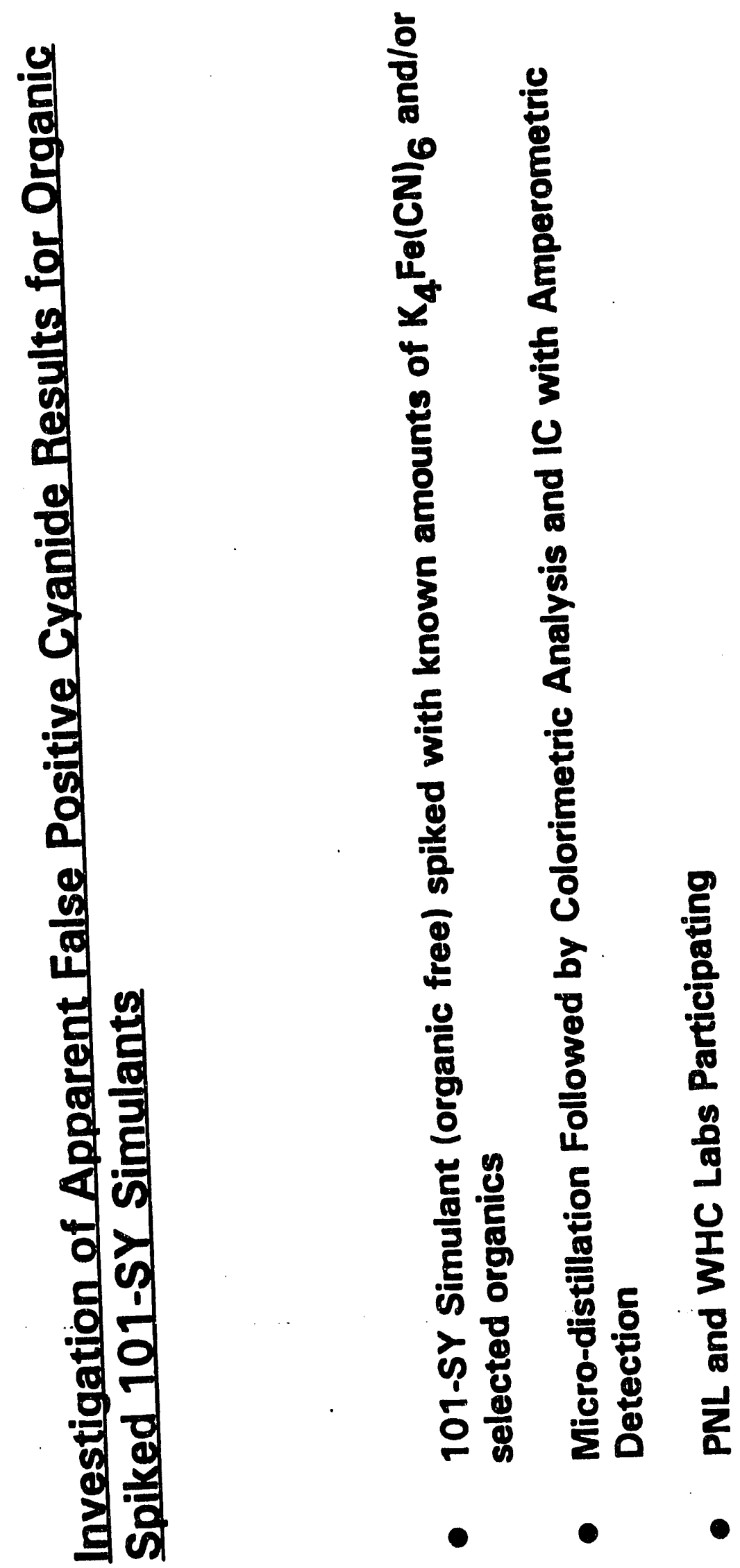


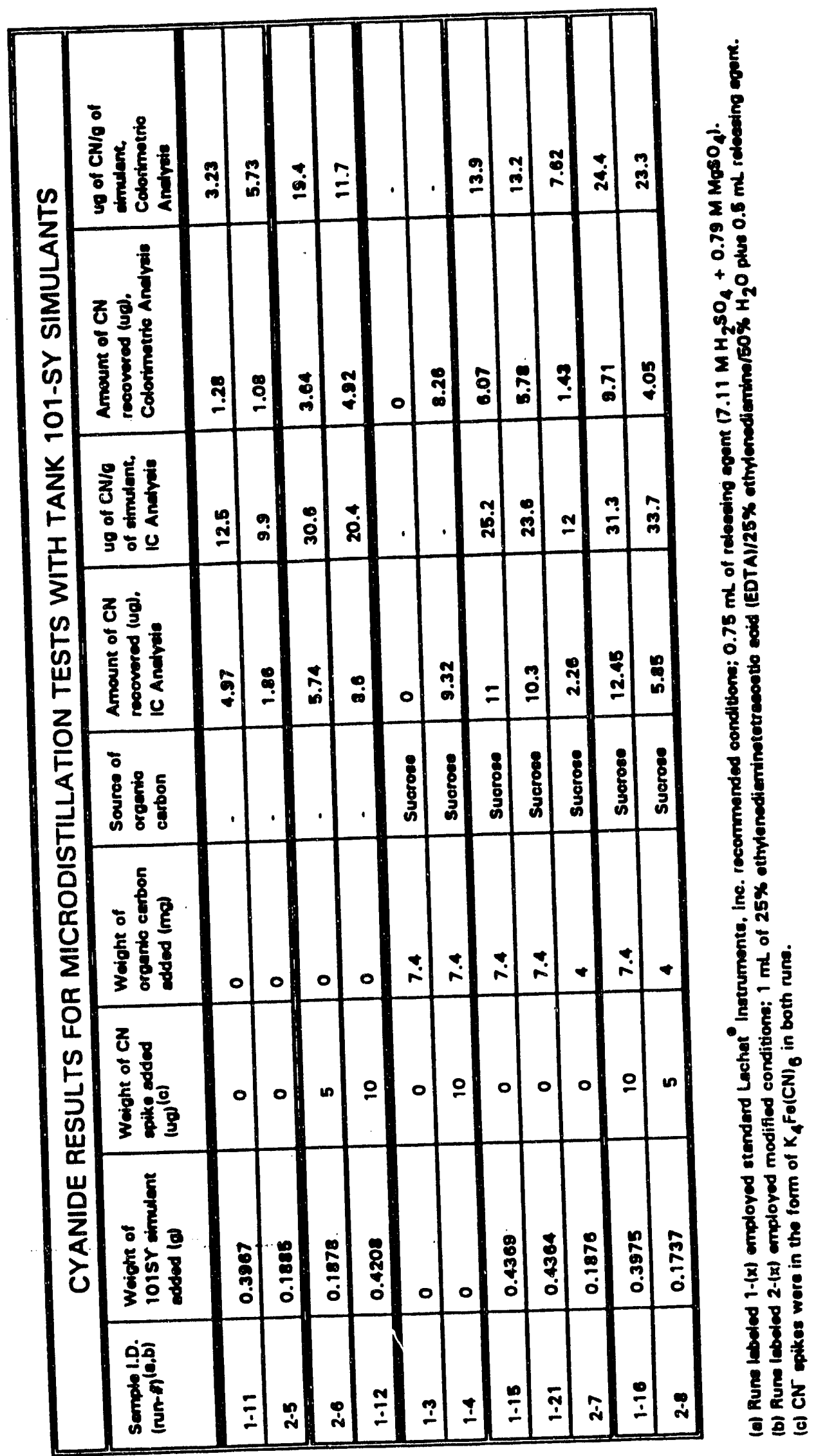


WHC-EP-0635

흥

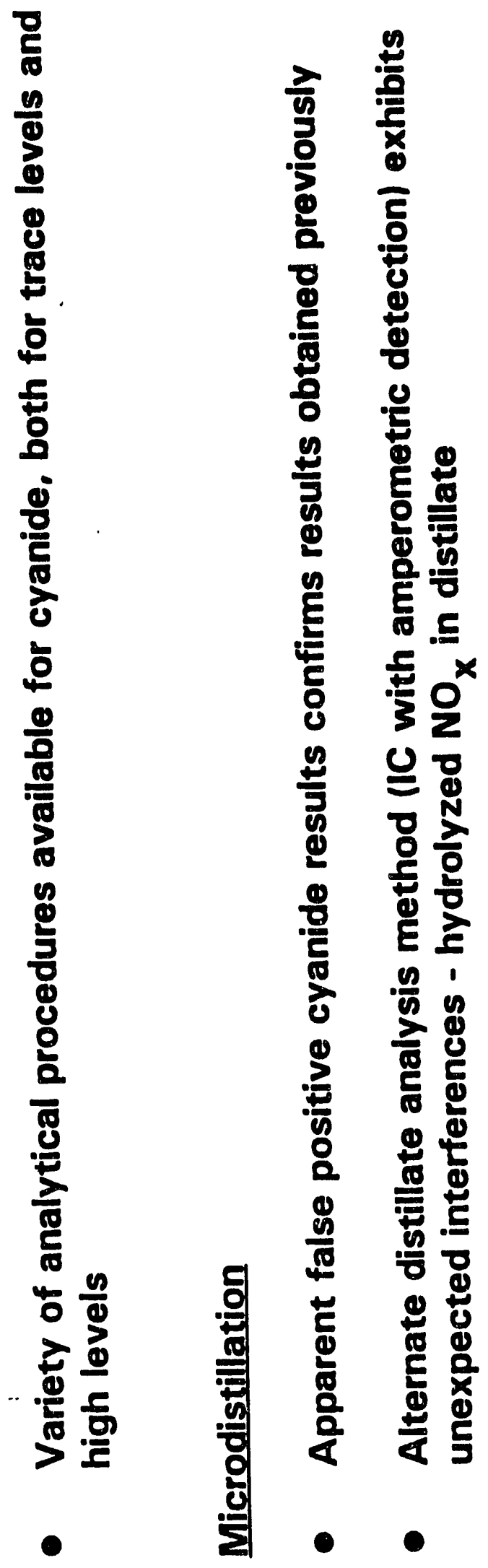


WHC-EP-0635
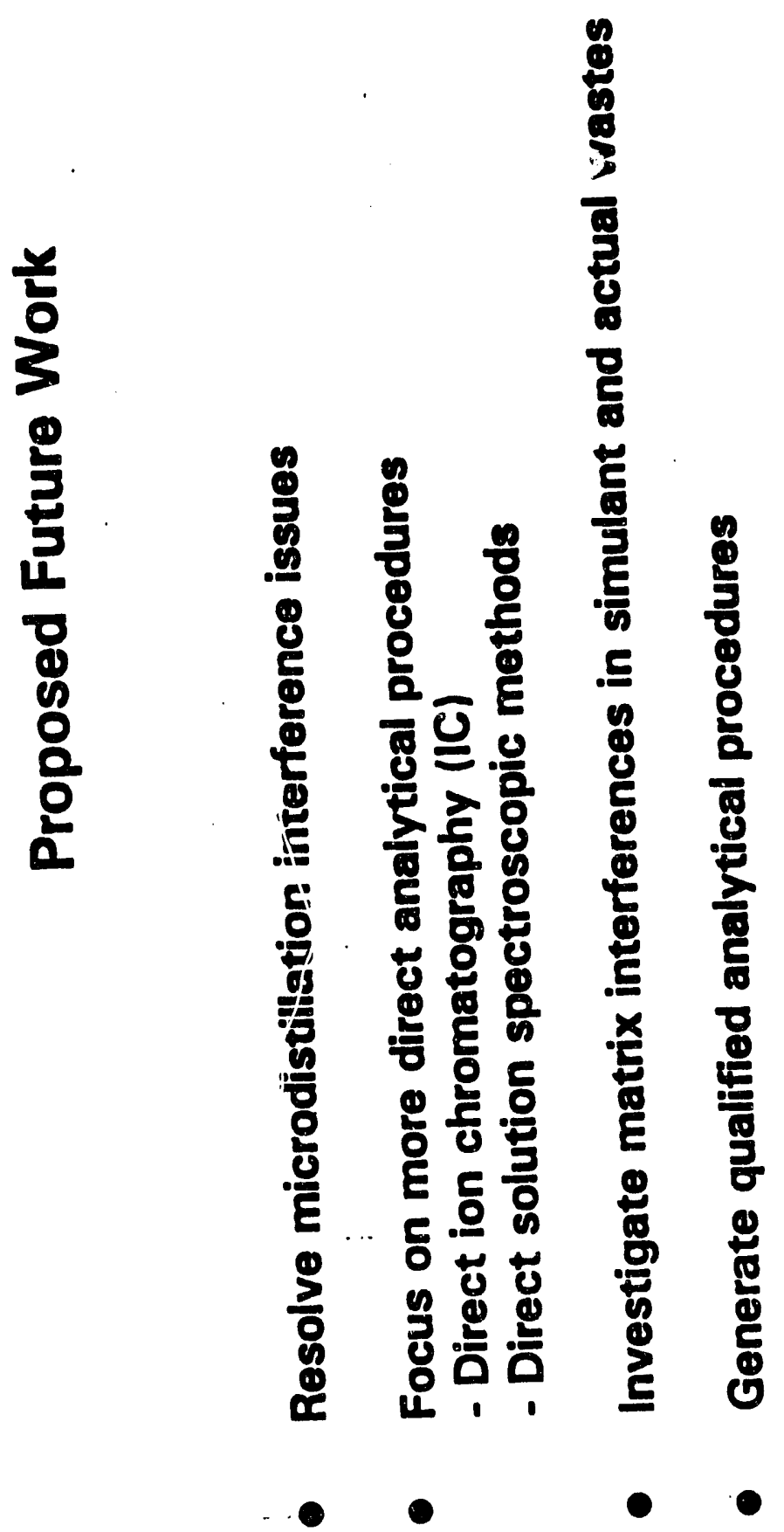
WHC-EP-0635

This page intentionally left blank. 
WHC-EP-0635

APPENDIX B

B-1 
WHC-EP-0635

This page intentionally left blank. 


\section{Battelle}

Pacific Northwest Laboratories
Proiect Number

Inemel Dientioution

File/LB

Daw January 13, 1993

To Robert J. Cash, R2-32 / Albert F. Moonan, R2-12

RECEIVED

From Karl H. Pool, P8-44 Tare fool

JAN 19 199?

Subjoc Total Cyanide Analysis Method Validation Test Plan and Schedule

A. F. NCONAN

After our meeting early Monday morning (1/11/93), I prepared the attached test plan and schedule as you requested. I hope you will agree that this plan is technically defensible and meets the requirements of your near term agenda.

Please call me on 376-1753 if you have comments and/or concerns.

In my opinion, executing this test plan is above and beyond the originally agreed upon scope of work for Task 307 of the "Methods Development and Technology Transfer Project." Please advise as to the best way of handling this situation from a project management point of view. I an not fully aware of the available options and your preferences.

KHP: cVin

At tachment 
Total Cyanide Analysis of Syntheric FeCN Flow Sheet Marerials and Tank C112. Core 34 Segment Samples - Method Yalidation Test Plan and Schedule

\section{INTRODUCTION}

The technical procedure to be used is PNL-ALO-285, titled "Total Cyanide by Remoce Microdistillation and Argentometric Titration for Samples Containing Greater than Approximately 0.1 Weight $\%$ of Total Cyanide". This procedure is currently in PNL's internal review cycle and therefore, is not officially approved for routine use at this time. The procedure needs to be validated as technically sound so that data generated in the future can be accepted as correct within reasonable limits.

The sequential arder of tests and approximate dates for completion of each are given below:

Preliminary test to be done before arrempring the validation cest marrix proper. Several modifications to the originally proposed sample dissolution and actual distillation conditions have shown promising results when applied to synthetic $101 \mathrm{SY}$ matrices. In particular, the dissolution solution has been modified to result in a higher $\mathrm{pH}$ environment (to preclude potential loss of free cyanide during sample dissolution) and the acidic "releasing solution" has been changed so that the actual distillation is carried out at $\mathrm{pH} \sim 4$.

The preliminary microdistillation test will apply these newer conditions to $\mathrm{Na}_{2} \mathrm{NiFe}(\mathrm{CN})_{6}$ materials. If the results from this test are favorable i.e., agreement of duplicates, $>90 \%$ spike recovery, and low blanks, these test conditions will be written into the final version of PNL-ALO285 and used in the actual validation process.

\section{Details of Preliminary Test}

Dissolution solution: $1 \mathrm{~mL}$ of $0.4 \mathrm{M} \mathrm{Na} 4 \mathrm{Y}$ (tetrasodium EDTA) $+1.1 \mathrm{M}$ en(ethylenediamine)

Releasing solution: $1 \mathrm{~mL}$ of $2 \mathrm{M}$ citric acid $+0.9 \mathrm{M} \mathrm{NH}_{4}^{+} \mathrm{H}_{2} \mathrm{NSO}_{3}^{-}+0.1 \mathrm{M}$

$\begin{array}{ll}\text { Analytical Finish: } & \mathrm{H}_{2} \mathrm{NSO}_{3} \mathrm{H} \text { (sulfumic acid } \\ \text { Argentometric tioration }\end{array}$

\section{Samples}

In Farm 2, duplicates, $\sim 100 \mathrm{mg}$ each

FeCN-36, duplicates, $\sim 10 \mathrm{mg}$ each

In Farm 2, spiked with WHC-2, duplicates, $\sim 50 \mathrm{mg}$ sample $+10 \mathrm{mg}$ spike 
Blunk (no sample)

$\mathrm{Cs}_{2} \mathrm{NiFe}(\mathrm{CN})_{6} \sim 10 \mathrm{mg}$

Standard Distillation conditions - $30 \mathrm{~min}$ at $125^{\circ} \mathrm{C}$

Measure $\mathrm{pH}$ of distillation residue after distillation.

This test will be completed by $1 / 15 / 93$.

\section{Yalidation Test Matrix}

\begin{tabular}{|c|c|c|c|c|c|}
\hline $\begin{array}{l}\text { Test } \\
\text { No. }\end{array}$ & $\begin{array}{l}\text { Sample } \\
\text { Materinl }\end{array}$ & $\begin{array}{c}\text { Sample Size } \\
(\mathrm{e})\end{array}$ & Spiked Samples * & $\begin{array}{l}\text { Control } \\
\text { Sample }\end{array}$ & Blank \\
\hline 1 & $\begin{array}{l}\text { In-Farm } 2 \text { (flow sheet } \\
\text { moteria) }\end{array}$ & $0.05,0.05,0.10$ & $\begin{array}{l}0.05 \mathrm{~g} \text { sample }+0.01 \mathrm{~g} \text { WHC- } \\
2 \text { in duplicate }\end{array}$ & $0.01 \mathrm{~g}$ WHC-2 & yes \\
\hline 2 & $\begin{array}{l}\mathrm{F} 6 \mathrm{CN}-36 \\
\left(\mathrm{Na}_{2} \mathrm{NiF} / \mathrm{CN}\right)_{6}, 34.5 \% \\
\mathrm{CN}^{-}\end{array}$ & $0.01,0.01,0.02$ & $\begin{array}{l}0.01 \text { g sample }+0.01 \mathrm{~g} \text { WHC. } \\
\text { 2, in duplicace }\end{array}$ & $0.01 \mathrm{~g}$ WHC-2 & yes \\
\hline 3 & Sogmeat $\mathrm{A}^{2}, \mathrm{k}$, Core 34 & $0.01,0.01,0.02$ & $\begin{array}{l}0.1 \mathrm{~g} \text { sample + } 1 \mathrm{mg} \text { WHC-2, } \\
\text { in duplicale }\end{array}$ & $0.01 \mathrm{~g}$ WHC- 2 & yes \\
\hline 4 & $\begin{array}{l}\text { Segment B, Care } 34 \\
\text { Tank C112 }\end{array}$ & $0.01,0.01,0.02$ & $\begin{array}{l}0.1 \mathrm{~g} \text { sample }+1 \mathrm{mg} \text { WHC-2, } \\
\text { in duplicale }\end{array}$ & 0.01 \& WHC-2 & yes \\
\hline 5 & $\begin{array}{l}\text { Segment C, Core } 34 \\
\text { Tank C112 }\end{array}$ & $0.01,0.01,0.02$ & $\begin{array}{l}0.1 \mathrm{~g} \text { sample + I mg WHC-2, } \\
\text { in duplicale }\end{array}$ & $0.01 \mathrm{~g}$ WHC-2 & yes \\
\hline 6 & $\begin{array}{l}\text { Segment D, Core } 34 \\
\text { Tank C112 }\end{array}$ & $0.01,0.01,0.02$ & $\begin{array}{l}0.1 \mathrm{~g} \text { sample }+1 \mathrm{mg} \text { WHC-2, } \\
\text { in duplicale }\end{array}$ & $0.01 \mathrm{~g}$ WHC-2 & yes \\
\hline
\end{tabular}

*Use WHC-2 as spiling material; predissolve in EDTAVen solution before adding to sample

This validation test matrix consists of 6 analytical sessions. Each tests consists of:

$$
\begin{aligned}
& \text { - one blank } \\
& \text { - one control sample } \\
& \text { - actual sample in triplicate, and } \\
& \text { - duplicate spiked samples. }
\end{aligned}
$$

Tests 1 and 2 utilize non-radioactive materials only. These tests will be carried out in 314 building as "bench top" experiments. Tests 1 and 2 will be completed by January 29, 1993 at the latest.

Tests 3 through 6 will be carried out in the B-bot cells of 325 building. Actual manipulations will be done by one of the hot-cell technicians (preferably Vaughn Hoppes). 
Conceivably tests 3 through 6 could be run concurrently with the bench top tests Nos. 1 and 2 . This concurrent timing is not recirmmended, however, due to potential unforescen difficulties with tests No. 1 and No. 2, as well as the limited quantity of care material available for these tests.

Another consideration is the availability of hot-cell personnel to do the actual work on tests 3 through 6. Scheduling priorities are deternined by others (Rick Steele, Gaylord King, et al.).

Even with these caveats, tests involving actual core materials should be finished by the end of February 1993. 
WHC-EP-0635

\section{DISTRIBUTION}

Number of Copies

\section{OFFSITE}

U.S. Department of Energy

EM 35, Trevion II

Washington, D.C. 20585

John C. Tseng

1

U.S. Department of Energy Idaho Operations Office 785 DOE Place

Idaho Falls, Idaho 83402

P. Gene Woodall

U.S. Department of Energy Savannah River Operations office P.0. Box A

Aiken, South Carolina 29808

Thomas C. Temple

1

David 0. Campbell

102 Windham Place

Oak Ridge, TN 37830

Donald T. Oakley

409 12th Sireet SW, Suite 310

Washington, D.C. 20024-2188

1

Arl in K. Postma

3640 Bail ard Road

Dallis, Oregon 97338

1

William R. Prindle 1556 Crestline Drive

Santa Barbara, CA 93105

1

Alfred Schneider 5005 Hidden Branches Drive Dunwoody, GA 30338

Battelle Columbus Laboratories 505 King Avenue

Columbus, $\mathrm{OH}$ 43201-2693

James A. Gieseke 


\section{DISTRIBUTION (cont)}

Number of Copies

OFFSITE

2

1

1

1

1

1

4
Brookhaven National Laboratory

Upton, NY 11973

Kamal K. Bandyopadhyay

Morris Reich

Desian Science, Inc.

163 Witherow Road

Sewickley, PA 15143

Gary Powers

$E G$ and $G$ Idaho, Inc.

P.0. Box 1625

Idaho Falls, Idaho 83415

William C. Schutte

Fauske and Associates. Inc.

16 W070 W. 83rd St.

Burr Ridge, IL 60521

Hans K. Fauske

Florida State University

Department of Chemistry B-164

Tallahassee, FL 32306

Greg R. Choppin

Hazards Research Corporation

200 Valley Road, Suite 301

Mt. Arlington, NJ 07856

Chester Grelecki

Los Alamos National Laboratory

P.0. Box 1663

Los Alamos, NM 87545

Steve F. Agnew

Steve W. Eisenhower

Thomas E. Larson

L. Harold Sullivan 
WHC-EP-0635

\section{DISTRIBUTION (cont)}

Number of Copies

\section{OFFSITE}

1

NUCON

P.0. Box 29246

Columbus, $\mathrm{OH} 43229$

Louis Kovach

1

Oak Ridge National Laboratory

David J. Pruett

P.0. BoX 2008

4501, MS-6223

Oak Ridge, TN 37831-6223

1

Oak Ridge National Laboratory

Emory D. Coll ins

P.0. Box 2008

7930, MS-6385

Oak Ridge, TN 37831-6385

1

Rice University

5211 Paisley

Houston, TX 77096

Andrew S. Veletsos

1

Science Applications International Corporation 12850 Middlebrook Road

Trevion I, Suite 300

Germantown, MD 20874

John M. Savel and

1

University of South Carolina

Department of Electrical and Computer Engineering Swearingen Engineering Center

Columbia, SC 29208

Joseph S. Byrd

1

University of Washington

Center for Process Analytical Chemistry

Chemistry Department BG-10

Seattle, WA 98195

Bruce R. Kowalski 
WHC-EP-0635

\section{DISTRIBUTION (cont)}

Number of Copies

QFFSITE

1

Vanderbilt University

P.0. Box 1596, Station B

Nashville, TN 37235

Frank L. Parker

1

West Valley Nuclear Services Co., Inc.

Rock Springs Road (Box 191)

West Valley, New York 14171

David K. Ploetz

1

Westinghouse Idaho Nuclear Co.. Inc.

1955 Freemont Ave.

P.0. Box 4000

Idaho Falls, Idaho $83403-4000$

Alan P. Hoskins

1

Westinghouse Savannah River Company

P.0. Box 616, 703-H

Aiken, South Carolina 29802

Paul d'Entremont

ONSITE

9

U.S. Department of Energy. Richland Field office

R. F. Christensen (5)

A4-02

R. E. Gerton

A4-02

A. G. Krasopoulos

A5-55

Public Reading Room

Al -65

RL Docket File

Pacific Northwest Laboratory

R. T. Allemann

K7-15

S. A. Bryan

P7-25

B. M. Johnson

T. E. Jones (10)

$\mathrm{K} 1-78$

M. A. Lilga

$\mathrm{K} 1-30$

K. H. Pool (10)

P8-38

R. D. Scheele

P8-44

G. F. Schiefelbein

P7-25

P8-38

Distr-4 


\section{WHC-EP-0635}

\section{DISTRIBUTION (cont)}

\section{Number of Copies}

ONSITE

Pacific Northwest Laboratory (cont)

D. M. Strachan

K2-38

PNL Technical files

$\mathrm{K} 1-11$

77

Westinghouse Hanford Company

H. Babad

R2-78

D. B. Bechtold

T6-09

J. B. Billetdeaux

R2-08

D. C. Board

S1-57

G. L. Borsheim

R2-11

V. C. Boyles

R1-49

S. L. Bradley

B3-06

R. J. Cash (5)

R2-32

M. D. Crippen

L5-31

G. M. Christensen

H4-21

R. D. Crowe

C. Defigh-Price

H4-62

D. R. Dickinson

R2-31

G. T. Dukelow (2)

L5-31

C. J. Forbes

K. D. Fowler

G. L. Fox

G. T. Frater

J. C. Fulton

K. A. Gasper

J. M. Grigsby

R2-32

R1-08

R2-11

L5-01

R1-51

R2-31

R2-08

T. W. Halverson

$\mathrm{H} 4-62$

D. G. Hamrick

R2-50

H. D. Harmon

D. L. Heer

RI-51

J. M. Held

R2-52

HO-38

R. D. House

R3-12

L. L. Humphreys

R2-83

M. N. Is I am

R2-50

D. W. Jeppson

R3-08

J. R. Jewett

L5-31

N. W. Kirch

W. L. Knecht

T6-09

R2-11

D. A. Marsh

$\mathrm{HO}-34$

J. D. McCormack

A3-05

J. M. McLaren

L5-31

J. E. Meacham

HO-34

N. J. Milliken

R2-32

A. F. Noonan

H4-62

R2-12 


\section{WHC-EP-0635}

\section{DISTRIBUTION (cont)}

Number of Copies

ONSITE

Westinghouse Hanford Company (cont)
R. S. Popielarczyk
R1-30
D. N. Price
R2-14
J. G. Propson
R2-18
R. E. Raymond
R1-80
I. E. Reep
R2-08
F. R. Reich
L5-63
E. L. Renner
R2-08
D. A. Reynolds
R2-11
D. C. Richardson
R2-31
C. P. Schroeder
L7-06
M. H. Shannon
N. L. Simon
B. C. Simpson (10)
H4-61
H. Toffer
R. K. Welty
R2-78
R2-12
HO-38
W. P. Whiting
R1-80
D. D. Wodrich
B3-25
D. D. Wodrich
R2-31
W. F. Zuroff
Central Files
B1 -59
Document Processing and Distribution (2)
EDMC
R2-14
L8-04
L8-15
Information Release Administration (3)
TFIC
H6-08
R1-08
RI-20 

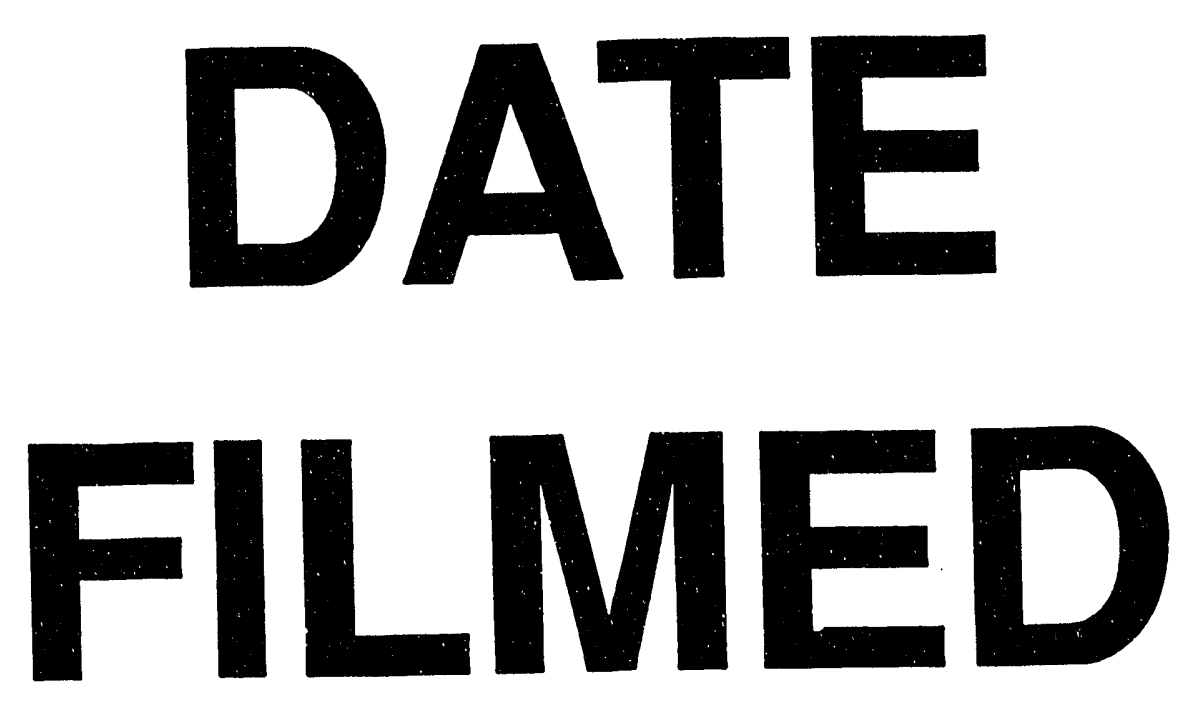

$8 / 09 / 93$
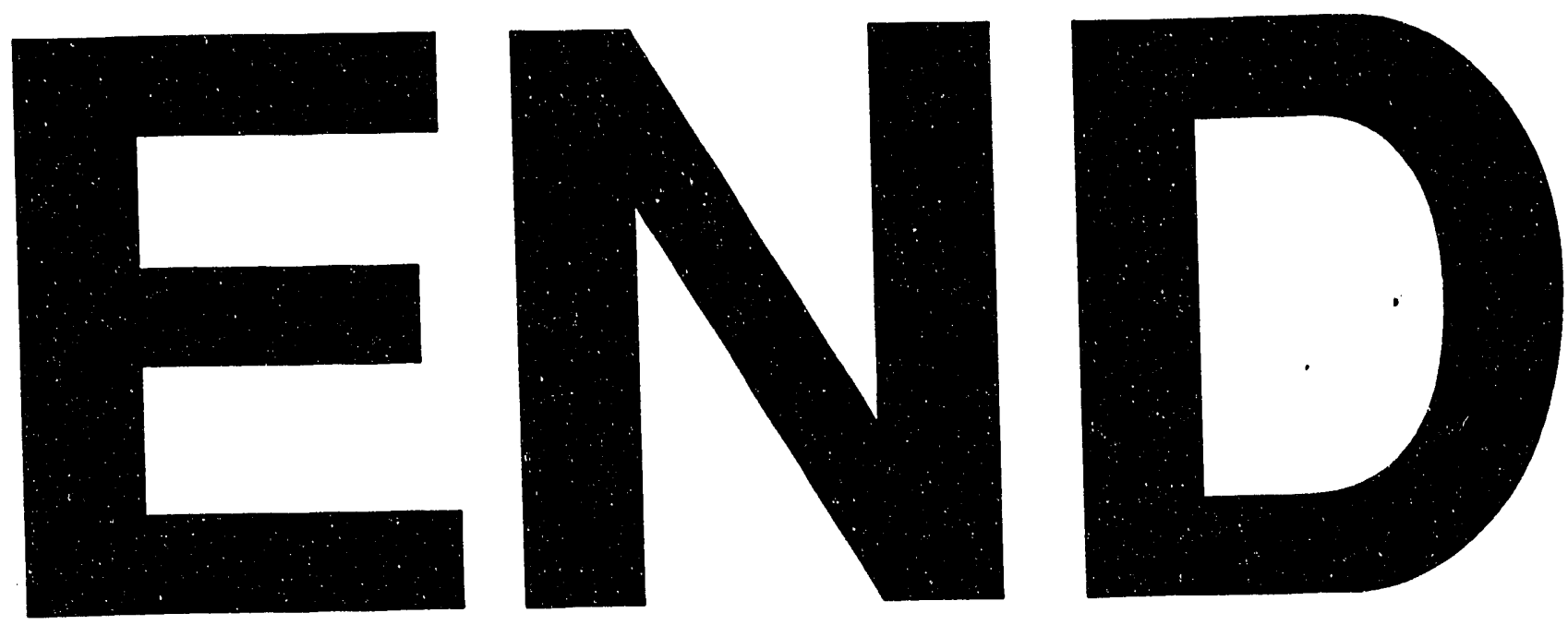
